\title{
Medievalista
}

Online

$28 \mid 2020$

Número 28

\section{El rol de los eclesiásticos en la construcción de la legitimidad "internacional" de la dinastía portuguesa de los Avis (1383-1433)}

The role of ecclesiastics in the construction of "international" legitimacy of the

Portuguese Avis dynasty (1383-1433)

\section{Néstor Vigil Montes}

\section{OpenEdition}

\section{Journals}

\section{Edición electrónica}

URL: http://journals.openedition.org/medievalista/3306

DOI: 10.4000/medievalista.3306

ISSN: $1646-740 X$

Editor

Instituto de Estudos Medievais - FCSH-UNL

\section{Edición impresa}

Paginación: 87-132

\section{Referencia electrónica}

Néstor Vigil Montes, «El rol de los eclesiásticos en la construcción de la legitimidad "internacional" de la dinastía portuguesa de los Avis (1383-1433)», Medievalista [En línea], 28 | 2020, Publicado el 01 julio 2020, consultado el 25 marzo 2021. URL: http://journals.openedition.org/medievalista/3306 ; DOI: https://doi.org/10.4000/medievalista.3306

Este documento fue generado automáticamente el 25 marzo 2021.

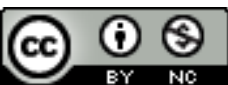

Mediavalista está licenciado com uma Licença Creative Commons - Atribuição-NãoComercial 4.0 Internacional. 


\section{El rol de los eclesiásticos en la construcción de la legitimidad "internacional" de la dinastía portuguesa de los Avis (1383-1433)}

The role of ecclesiastics in the construction of "international" legitimacy of the Portuguese Avis dynasty (1383-1433)

Néstor Vigil Montes

\section{NOTA DEL AUTOR}

Este estudio ha sido posible gracias al disfrute de una beca posdoctoral (bolsa de pósdoutoramento) financiada por la Fundação para a Ciência e a Tecnologia do Ministério da Educação e Ciência de Portugal (SFRH/BPD/94257/2013), e inserto dentro del proyecto "DEGRUPE - A dimensão europeia de um grupo de poder: o clero e a construção política das monarquias ibéricas (XIII-XV) / The European Dimension of a Group of Power: Ecclesiastics and the political State Building of the Iberian Monarchies (13th-15th centuries)" financiado por fondos nacionales a través de la FCT/MCTES y cofinanciado por los fondos europeos FEDER a través del programa COMPETE (PDTC/ EPH-HIS/4964/2012).

1 La proclamación de Juan I como soberano de Portugal en las Cortes de Coimbra de 1385 supuso un auténtico "golpe de estado", ya que el advenimiento de la nueva dinastía Avis significó la ruptura con la legalidad vigente, según la cual el trono portugués debería haber sido ocupado por Beatriz de Portugal, hija de Fernando I de Portugal. Todo "golpe de estado" implica un proceso de legitimidad, y en el caso de Juan I de Portugal este supuso llevar a cabo una ingente actividad diplomática en la que procuró la superviviencia y la legitimidad de la nueva dinastía Avis. Comprender las claves "internacionales" ${ }^{2}$ de este contexto supone entender muchas de las tendencias 
geoestratégicas de la política exterior portuguesa, que con algunos matices perduraron hasta la actualidad, y es que los avatares de la llegada al trono portugués de la dinastía Avis supusieron una obligada entrada en el complejo contexto europeo con la elaboración de una primera política exterior coherente, esto supuso dejar atrás la actitud dubidativa en esta materia de su antedecesor en el trono, Fernando I de Portugal, y tomar partido con firmeza en cuestiones como la Guerra de los Cien Años o el Gran Cisma de Occidente ${ }^{3}$.

2 El nuevo monarca mediante una calculada estrategia logró cumplir el primer objetivo encomendado por los sectores sociales en rebeldía que le encumbraron ${ }^{4}$, el de consolidar la independencia del reino de Portugal frente a la amenaza exterior proveniente del poderoso vecino castellano, cuyo monarca Juan I de Castilla reclamaba los derechos sucesorios al trono luso de su esposa Beatriz de Portugal ${ }^{5}$. Para mantener esa independencia frente a un adversario que le superaba en tamaño y población, se encontró con la necesidad de conseguir apoyos provenientes de otros reinos interesados en oponerse a las aspiraciones castellanas. En este sentido, su aliado natural en la política peninsular, la Corona de Aragón, no pudo ser su aliado frente a Castilla, puesto que se encontraba en una situación interna delicada ${ }^{6}, \mathrm{y}$ además, había entrado en la órbita de los intereses castellanos y franceses, al haberse decantado por el papado aviñonense $e^{7}$. Por consiguiente, el único reino que podía garantizar la supervivencia de la nueva dinastía era el de Inglaterra, cuya dinastía gobernante estaba enfrentada con la dinastía castellana de los Trastámara desde sus orígenes, dado que en la Guerra Civil Castellana (1351-1369) tomaron partido por los derrotados petristas y posteriormente reclamaron los derechos al trono de Constanza de Castilla, casada con el infante Juan de Gante desde $1371^{8}$. La alianza entre las monarquías inglesa y portuguesa fue ratificada en el Tratado de Windsor de 1386 entre Juan I de Portugal y Ricardo II de Inglaterra9.

3 El advenimiento de la nueva dinastía también supuso una nueva alteración en la política de fidelidades en el Gran Cisma de Occidente. El precedesor en el trono portugués de Juan I de Portugal, Fernando I de Portugal, había llevado a cabo una errática estrategia en este sentido en la que incluso llegó a cambiar en varias ocasiones su fidelidad entre los distintos pontífices dependiendo de la situación en la que se encontraban sus relaciones con los vecinos castellanos ${ }^{10}$. Fernando I de Portugal se decantó en un primer momento (1378-1379) por Clemente VII, es decir, por el papa aviñonés, pero la guerra con Castilla de 1380 y la alianza con Inglaterra forzaron un cambio de obediencia, y por tanto, al consecuente reconocimiento de la autoridad de Urbano VI. Finalmente se alcanzó un acuerdo de paz con Castilla que supuso un nuevo acercamiento al reino vecino, esto se tradujo en volver a tomar partido por la causa clementista ${ }^{11}$, al mismo tiempo que concedió a Juan I de Castilla en matrimonio a su heredera Beatriz de Portugal. Una vez que falleció Fernando I de Portugal, la causa de su hija y de Juan I de Castilla fue defendida por los sectores clementistas, y el futuro Juan I de Portugal, entonces maestre de Avis, aglutinó la causa urbanista, la única que tenía sentido geoestratégico para mantener la independencia del reino de Portugal frente a Castilla, al unirse al pontífice que se encontraba enfrentado a los castellanos, y al que seguían sus potenciales aliados ingleses. Con el acercamiento al pontífice romano, el monarca portugués obtuvo, no sin antes de llevar a cabo un proceso arduo de negociación, la eliminación de los dos impedimentos que pesaban sobre la persona de Juan I para ejercer como monarca portugués: su condición de bastardo como hijo 
natural de Pedro I de Portugal ${ }^{12}$, y su estatus de religioso como Maestre de Avis que le impedía contraer matrimonio con Filipa de Lancaster ${ }^{13}$.

El nuevo monarca habiendo alcanzado los suficientes acuerdos con otros poderes políticos para procurarse su supervivencia y su legitimidad, tras décadas de conflicto con los castellanos y diversas negociaciones de treguas, logró alcanzar un primer acuerdo de paz, el Tratado de Ayllón de 1411, por el que la monarquía castellana lo reconoció definitivamente como soberano legítimo de Portugal y rechazaba continuar luchando por las aspiraciones dinásticas de Beatriz de Portugal ${ }^{14}$. Igualmente Carlos VI de Francia como aliado de los castellanos se avino a aprobar el tratado de paz y también reconocer al soberano luso ${ }^{15}$. Posteriormente este acuerdo con los castellanos fue renovado con un nuevo tratado de paz en $1423^{16}$ y establecida definitivamente en el Tratado de Medina del Campo de $1433^{17}$. Una vez garantizada la supervivencia de su reinado, el monarca portugués emprendió diversas acciones en política exterior conducentes a aumentar el prestigio de la nueva dinastía Avis en las que los eclesiásticos tuvieron cierta influencia. Las más destacadas fueron la continuación de la empresa bélica contra los sarracenos en los territorios norteafricanos con la conquista de Ceuta en $1415^{18} \mathrm{y}$ la actuación portuguesa en los concilios ecuménicos con el objetivo de tener un protagonismo en la solución del cisma ${ }^{19}$.

5 En toda esa ingente actividad diplomática destinada a la construcción de la legitimidad "internacional" de la dinastía portuguesa de Avis observamos una destacada actuación de diversos eclesiásticos, algunos de ellos figuras destacadas como João Afonso Esteves de Azambuja o Rui Lourenço. Un hecho que no había pasado inadvertido en la historiografía sobre el reinado de Juan I de Portugal, pero sobre el que todavía quedan algunas cuestiones por responder, tales como: ¿quiénes fueron los diversos eclesiásticos que intervinieron en esa política exterior?, ¿por qué fueron elegidos para dicha tarea?, ¿en qué situaciones fueron requeridos y en cuáles no?, ¿cuáles son los intereses de cada uno de los eclesiásticos?, ¿Cuál fue el resultado de esa aportación?

Para alcanzar respuestas claras sobre estas cuestiones hemos procedido a realizar un estudio prosopográfico de los principales eclesiásticos que han participado en la diplomacia joanina, en este sentido hemos tenido en cuenta no solamente su aportación en labores diplomáticos sino que también hemos analizado otros factores importantes en este tipo de análisis, tales como: orígenes familiares, formación académica, relación con la dinastía reinante, participación en otros órganos de la administración regia, colaboración en la política eclesiástica, y recompensa regia y trayectoria eclesiástica.

7 Con tal fin hemos recurrido a la bibliografía sobre esta cuestión ${ }^{20}$ y a toda la documentación necesaria para ampliar los datos aportados por otros historiadores, de este modo hemos analizado documentación de múltiples archivos dependiendo de cada uno de estos objetivos. En primer lugar, para ampliar sobre la cuestión de la participación de los eclesiásticos en diplomacia resulto de enorme utilidad acceder a los grandes corpora en los que se recopila documentación para la diplomacia del Arquivo Nacional de Torre do Tombo y del Archivo General de Simancas ${ }^{21}$. En segundo lugar, para adentrarnos en las cuestiones relacionadas con la concesión pontificia de privilegios al monarca portugués y a los eclesiásticos que acudían a la corte papal en representación de su rey, resultan enormemente interesantes los asientos de los registros pontificios del Archivo Secreto Vaticano y la colección de bulas del Arquivo Nacional da Torre do Tombo ${ }^{22}$. Finalmente, para conocer los detalles de la formación académica de aquellos eclesiásticos que han podido acudir a la Universidad de Bolonia, 
hemos podido analizar los libros de registro de títulos de esa institución académica y los registros de los notarios de esa localidad italiana ${ }^{23}$.

8 Con todo ello podremos finalmente determinar el grado de influencia de los eclesiásticos en la política exterior joanina, y definir las pautas de un caso paradigmático en el estudio de la aportación de los eclesiásticos en la construcción política de las monarquías medievales del Occidente Europeo.

\section{Los eclesiásticos en la elaboración de la política exterior joanina}

9 Durante la Baja Edad Media, la política exterior de los reinos fue controlada y determinada directamente por el monarca siguiendo las recomendaciones de sus consejeros y otros personajes de destacada relevancia en la administración. Un carácter personalista de la política exterior, cuya principal razón es que eran conscientes de que se trataba de una materia de especial responsabilidad y competencia como para delegarla a administradores profesionales ${ }^{24}$. No podemos conocer con exactitud cómo se elaboraba esa política exterior, puesto que no contamos con fuentes documentales de la actividad del consejo regio y menos aún de los posibles debates extraoficiales que pudieran tener consecuencias en las decisiones tomadas por el monarca. Lo que sí podemos reconstruir a través del análisis prosopográfico, es la trayectoria de aquellos eclesiásticos que sabemos de su influencia en la diplomacia regia, para poder acercarnos a cuáles podrían ser sus intereses y su valía en la elaboración de las relaciones "internacionales".

Las bases de la política exterior joanina se desarrollaron en su primera etapa de gobierno caracterizada por la búsqueda de supervivencia y reconocimiento de esa nueva dinastía, la cual podemos demarcar entre la llegada al poder en 1383 y los inicios de la expansión africana con la conquista de Ceuta en 1415. Una etapa que coincide con un protagonismo de primera magnitud de los eclesiásticos dentro del gobierno de la nueva dinastía, una etapa de connivencia entre el nuevo monarca y un renovado estamento clerical compuesto por eclesiásticos fieles a la monarquía ${ }^{25}$.

11 La composición del alto clero en los primeros compases del reinado de Juan I de Portugal tuvo una relación directa con la defensa de la causa romana y de la nueva dinastía portuguesa. En ese sentido hubo una purga de los obispos simpatizantes de la causa aviñonense, los cuales pertenecían a sedes sufragáneas de los arzobispados de Santiago de Compostela y Sevilla ${ }^{26}$, nos referimos a hombres como: Martinho Zamora (Lisboa) ${ }^{27}$, Martinho (Évora), Pedro Lourenço (Lamego), Afonso Domingues de Linhares (Guarda) o Pedro (Silves) ${ }^{28}$.

12 En la mencionada cronología, los eclesiásticos desempeñaron un importante papel en las dos principales instituciones de la administración joanina: el consejo regio ${ }^{29}$ y la cancillería regia (desembargo) ${ }^{30}$, conformando un tercio y un sexto de sus integrantes respectivamente. En esa primera administración joanina podemos reconocer claramente dos perfiles de eclesiástico en la alta administración: el de "hombre nuevo" que por su apoyo desde los primeros momentos del reinado recibe la confianza regia y es premiado con una carrera eclesiástica; y el de eclesiástico ligado a anteriores reinados que toma partido por el cambio dinástico. Por consiguiente, no existió discordia alguna entre el clero como estamento y las relaciones "internacionales", ni de 
forma individual ni tampoco colectivamente como podemos comprobar en la falta de constancia de su protagonismo en las cortes portuguesas, una asamblea que en este periodo fue llamada con frecuencia por la necesidad de financiación para mantener las actuaciones bélicas contra los castellanos ${ }^{31}$.

Posteriormente, en la segunda etapa del reinado de D. João I que se desarrolló entre 1416 y 1433, fueron asentadas las bases de la política exterior y solamente se buscó profundizar la posición de la nueva dinastía en el contexto "internacional". Sin embargo, en este momento la presencia de los eclesiásticos se vió reducida al mínimo al producirse un divorcio entre la monarquía y la iglesia portuguesa ${ }^{32}$. Las causas anteriores de unión entre el monarca y los eclesiásticos portugueses habían dejado de tener efecto ya que ese catalizador que era el cisma se había extinguido con el conciliarismo, a lo que debemos de añadir unas ansias regalistas de una monarquía fortalecida y legitimada en el espíritu de expansión ultramar de la fe cristiana. El momento coincide con el fallecimiento de todos los eclesiásticos del primer periodo del reinado, y a pesar de que las principales mitras fueron ocupadas por familiares del monarca como Fernando da Guerra en Braga y Pedro de Noronha en Lisboa ${ }^{33}$, los eclesiásticos fueron apartados sistemáticamente de la administración joanina y de gran parte de la labor diplomática.

14 A continuación, analizaremos detenidamente las personalidades eclesiásticas que influyeron directamente en la primera fase del reinado joanino, la de construcción de la política exterior de la nueva dinastía. De esta forma pretendemos desvelar quienes dentro del clero eran esos "hombres nuevos" de la administración joanina y quienes eran esos hombres procedentes de la administración fernandina, para determinar cuál era su aportación en la construcción de la política exterior.

\subsection{Eclesiásticos en los "hombres nuevos" de la primera administración joanina}

Los eclesiásticos que forman parte de los "hombres nuevos" en los inicios de la administración joanina son nobles de segundo rango que decidieron apoyar desde un primer momento la causa del mastre de Avis. Consecuencia de ello destacaron por su enorme cercanía y confianza a la figura regia, siendo designados como miembros del consejo real $^{34}$. Al mismo tiempo fueron recompensados con una meteórica carrera eclesiástica de nuevo cuño en la que desempeñaron cargos de relevancia desde un primer momento. Dentro de este grupo de "hombres nuevos" encontramos a eclesiásticos como Martim Afonso de Charneca que fue nombrado obispo de Coimbra en $1386^{35}$ y arzobispo de Braga en $1398^{36}$; a João Afonso Esteves Azambuja que fue nombrado obispo de Silves en 1389, de Oporto en 1391, de Coimbra en 1398, arzobispo de Lisboa en 1402, y finalmente alcanzó el cardenalato con el papa pisano João XXIII en $1411^{37}$; y a João Eanes de quien tenemos las primeras noticias de su designación como obispo de Évora en $1385^{38}$.

Aquellos "hombres nuevos" cuyos orígenes familiares nos son conocidos comparten el hecho de que procedían de familias de la baja nobleza que ya habían colaborado en la corte de anteriores monarcas, pero que fueron firmes defensoras del cambio dinástico ante la esperanza de progresar socialmente. Martim Afonso da Charneca era hijo de Afonso Pires da Charneca, castellano de nacimiento, pero que tuvo que refugiarse en Portugal tras haber sido perseguido por Pedro I de Castilla ${ }^{39}$. Una vez allí entró al 
servicio de la corte de Fernando I de Portugal como escribano de la puridad ${ }^{40}$. Asimismo, Martim era hermano de Afonso Peres da Charneca, una de las personas que ayudaron al maestre en la defensa del Reino ${ }^{41}$ y participaron en la batalla de Aljubarrota en 1385, en la que fue nombrado caballero ${ }^{42}$. Por todos estos servicios fue premiado con la concesión regia del señorío de Alcáçovas ${ }^{43} \mathrm{y}$ de unas viñas y lagares en Lisboa $^{44}$. Por su parte, João Afonso Esteves de Azambuja era nieto de João Esteves de Azambuja, vasallo de Pedro I de Castilla ${ }^{45}$, e hijo de Afonso Esteves de Azambuja, reposteiro-mor de Pedro I de Portugal ${ }^{46} \mathrm{y}$ vasallo del conde João Afonso Tello ${ }^{47}$, por lo que participó en la armada que este capitaneó en la Tercera Guerra Fernandina ${ }^{48}$. Posteriormente, defendió la causa del maestre de Avis y fue premiado en 1384 con el señorío de Salvaterra de Magos, Sacarabotão y Lezíria da Atalaia (Vila Nova de Barquinha) por los servicios realizados "en esta guerra que habíamos por exaltación del reino" y por los prestados a sus antecesores Pedro I y Fernando I de Portugal ${ }^{49}$. Afonso Esteves de Azambuja falleció antes del 16 de junio de 1393, fecha en la que Juan I de Portugal concedió su señorío a su hijo, que entonces era obispo de Oporto ${ }^{50}$. Asimismo, João Afonso Esteves de Azambuja era sobrino de João Esteves de Azambuja, alcaide mayor de Lisboa y privado de Fernando I de Portugal ${ }^{51}$.

En cuanto a la formación académica no encontramos tanta homogeneidad, puesto que mientras Martim Afonso da Charneca tuvo una reconocida etapa boloñesa, otras personalidades no alcanzaron ese nivel académico. Como hemos señalado Martim Afonso da Charneca estudió en la Universidad de Bolonia ${ }^{52}$ y alcanzó el título de doctor en derecho civil el 4 de julio de 1382, así como atestigua el correspondiente apunte en el Libri segreti del Collegio di diritto civile $e^{53}$. Este fue resultado de una prolongada estancia como estudiante en la mencionada universidad, desde al menos $1376^{54}$, en la que también obtuvo el grado de licenciado en decretos - es decir, en derecho canónico entre esa fecha y la obtención del título de doctor ${ }^{55}$. Asimismo, parece que su intención inicial no era la de regresar a su lugar natal, sino la de desarrollar su carrera como docente en la propia universidad, donde llegó a ejercer como profesor en $1383^{56}$. Sin embargo, es probable que la muerte de Fernando I de Portugal y la crisis sucesoria precipitasen su vuelta a Portugal y el cambio en su itinerario profesional. Todo esto contrasta con el caso de João Afonso Esteves de Azambuja, del que únicamente sabemos que alcanzó el título de bachiller en decretos en un momento anterior a mayo de $1384^{57}$, el cual probablemente fue obtenido en el Estudio Geral de Lisboa ${ }^{58}$. También, con el caso de João Eanes, del que no tenemos constancia de que hubiese obtenido titulo alguno ${ }^{59}$.

Como su propio nombre indica, son hombres nuevos sin apenas experiencia en gobernación que entraron a dirigir los órganos más importantes de la administración regia. Además de su aportación al consejo regio de estas tres personalidades, tenemos constancia del trabajo en la cancillería regia (en Portugal conocida como el desembargo regio) como encargados de la redacción de las cartas regias de Martim Afonso de Charneca (1384-1397) ${ }^{60}$ y João Afonso Esteves de Azambuja (1384-1395) ${ }^{61}$. Asimismo, tal y como analizaremos con detenimiento en el siguiente capítulo, como personas de confianza del monarca también colaboraron en diversas embajadas, aunque en esta faceta particular destaca la participación de João Afonso Esteves de Azambuja que con al menos media docena de misiones en el exterior en diversos ámbitos: corte papal, reino castellano, concilios ecumémicos..., alcanzó cierta especialización en la representación exterior. 

corona. Por tanto se trata de personas cuyas carreras dependen de su fidelidad a la figura regia y que supeditan todas sus acciones al interés del monarca, son lo que Bernard Guenee definió como: "servidores de la corona que a su vez se sirven de la propia corona" ${ }^{2}$. No van a tener ningún problema para seguir la política eclesiástica de mayor interés para la corona aunque sea costa de sus propias diócesis, como podemos interpretar de la permuta a la corona del señorío episcopal bracarense realizada por Martim Afonso de Charneca en $1402^{63}$ o de la venta a la corona del señorio epicopal portocalense por parte de João Afonso Esteves de Azambuja en $1406^{64}$. En las relaciones con la cabeza de la iglesia también seguirán la defensa de los intereses reales, por lo que no tendrán problema por comenzar siendo urbanistas convencidos y cuando los tiempos cambien convertirse en patrocinadores de la solución conciliar o incluso apoyar al papado pisano.

\subsection{Rui Lourenço, un eclesiástico de carrera en la primera administración joanina}

La administración joanina no se limitó a reclutar "hombres nuevos" recompensados con carreras eclesiásticas, sino que también se nutrió de un eclesiástico con experiencia en la burocracia de los anteriores monarcas, pero que por diversas razones decidieron formar parte de la causa del maestre de Avis, ese eclesiástico es Rui Lourenço65.

21 Rui Lourenço fue uno de los protagonistas de la embajada compartida con los castellanos en 1379 que tenía por objeto recabar información en la corte de los dos papas sobre lo sucedido en los prolegomenos del Gran Cisma de Occidente ${ }^{66}$, la cual tuvo como desenlace el apoyo inicial a la causa clementista de ambas monarquías. Posteriormente, no tendría reparos en seguir el cambio de fidelidad a la causa urbanista de Fernando I de Portugal en 1381 coincidiendo con la alianza con los ingleses para el reinicio de las hostilidades con los castellanos conocido como Tercera Guerra Fernandina en la que de este modo un conflicto por la legitimidad dinástica se encubrió como cruzada cismática. Sin embargo, Rui Lourenço no estuvo dispuesto a retornar a la causa clementista cuando D. Fernando I de Portugal firmó el Tratado de Salvaterra de Magos en 1383 por el que finalizaba las hostilidades y acordaba el enlace matrimonial entre Juan I de Castilla y Beatriz de Portugal, su hija y única heredera del trono luso ${ }^{67}$. De hecho el eclesiástico fue protagonista en la Asamblea de Santarem de 1383 donde se dio una réplica de los urbanistas a la arenga proclamada por el cardenal Pedro de Luna con la intención de convencer a los portugueses del retorno a la causa clementista ${ }^{68}$ Por tanto, no vió con malos ojos la llegada de un candidato regio cuyas pretensiones sobre la fidelidad pontificia eran similares, y formó parte en la proclamación de Juan I de Portugal ${ }^{69}$.

Estamos ante una de las personalidades más cultas dentro de la corte portuguesa, algo de lo que era consciente el cronista Fernão Lopes al presentarlo como "grande leterado" ${ }^{\text {" }}$. Rui Lourenço había alcanzado el título de licenciado en decretos en la especialidad de derecho canónico por la Universidad de Bolonia desde $1376^{71}$ y había demostrando sólidos conocimientos de derecho romano (Corpus Iuris Civilis, Digesto...) y de derecho canónico (decretales de Graciano y de Gregorio IX) en la mencionada respuesta a la arenga del clementista Pedro de Luna ${ }^{72}$. A todo esto hay que añadir que su bien más preciado era una biblioteca repleta de títulos de derecho, la cual fue legada

Medievalista, 28 | 2020 
en su testamento a favor de las iglesias de Coimbra, Lisboa y Silves a cambio de misas de aniversaria ${ }^{73}$. En un documento por el que se da fe de la entrega de los libros por parte de su sobrino y testamentario Álvaro Martínez ${ }^{74}$, podemos observar la enumeración de las obras que componían la colección, entre ellas algunas referencias del saber jurídico de la época que entremezcla las obras clásicas del derecho romano, las colecciones decretales de los pontífices, y los comentarios de juristas de la escuela de Bolonia.

Además, era una personalidad con enorme experiencia en la burocracia que desempeñó un papel de consejero en la corte de D. Fernando I sin ser reconocido como tal ${ }^{75}$, aunque puede que ese antiguo cargo fuera ocultado a propósito por la administración joanina ante el establecimiento de la prohibición de ejercer cargos públicos a aquellos que fueran consejeros en el reinado fernandino, acordada por las cortes de Coimbra de $1385^{76}$. En la corte fernandina le fueron confiadas diversas misiones en Castilla como la embajada de 1380 para negociar el matrimonio de la infanta Beatriz de Portugal con el príncipe Enrique de Castilla ${ }^{77}$, o la negociación del Tratado de Pinto de 1382, en el que se profundizó sobre las consecuencias del matrimonio que finalmente tendría lugar entre Beatriz de Portugal y el recién enviudado Juan I de Castilla ${ }^{78}$, en lugar de su joven heredero. Posiblemente, por aquel entonces Rui Lourenço mantenía comunicación con la oposición liderada por el maestre de Avis, e incluso se llega a afirmar que el eclesiástico comunicó al futuro monarca que no pudo hacer más para que el tratado fuese más favorable a sus intereses ${ }^{79}$.

Rui Lourenço participó activamente en la administración joanina desde su contribución en las cortes de Coimbra de 1385. En ningún documento aparece nombrado como consejero real, pero tenemos sospecha de que pudo ejercer este cargo de facto ${ }^{80}$ y no fuese reconocido por su pasado fernandino, por otra parte tenemos la noticia de su propuesta como consejero por parte de los representantes urbanos de las cortes de Coimbra $^{81}$. Sin embargo si aparece en los registros como desembargador real (1386-1401), conservándose un total de 277 documentos suscritos bajo su autorización ${ }^{82}$, un cargo que nos indica su proximidad a la corte joanina ya que según Armando Luís de Carvalho Homem en aquella cronología no se diferenciaba claramente del puesto de consejero ${ }^{83}$.

A diferencia de los "hombres nuevos", este eclesiástico destaca más por su trayectoria que por su fidelidad a la monarquía, tanto en sus inicios en el reinado fernandino como en la etapa joanina. No parece que su interés sea la promoción en su carrera sino la defensa de la causa del papa romano convergiendo de este modo con los intereses "internacionales" del cambio dinástico. No obstante, su preparación y su trayectoria resultan de enorme utilidad a la nueva administración para cuestiones de política exterior ya que tiene una forjada experiencia en dos cuestiones vitales para la nueva estrategia joanina: la cuestión del Cisma de Occidente y el eterno conflicto con el vecino castellano. Por todo ello podemos considerar a Rui Lourenço como un verdadero servidor del estado, o mejor dicho, de la corona ${ }^{84}$, que sin esperar recompensa alguna, consagró sus fuerzas a una causa como la del papado romano que consideraba como representativa del bien común de los súbditos de la monarquía portuguesa como miembros de la Universitas Christiana.

26 A pesar de ser una de las figuras clave para la comprensión de la política exterior joanina, no disponemos de un estudio sobre su trayectoria, cuya importancia es comparable a la de otros jurisconsultos laicos que también contaban con experiencia en la corte fernandina cuando decidieron apoyar a la nueva dinastía, a saber: João das 
Regras ${ }^{85}$ y Gil do Sem, acompañantes de Rui Lourenço en la respuesta contra Pedro de Luna en la asamblea de Santarém; y Lourenço Anes de Fogaça, la personalidad con mayor experiencia en cuestiones diplomáticas que fue enviado a las cortes papal y de los reinos de Inglaterra, Francia y Castilla ${ }^{86}$.

\section{Los eclesiásticos como ejecutores de la política exterior de Juan I de Portugal en misiones diplomáticas}

La labor de los eclesiásticos en política exterior no se limitaba a su cuota de participación en las instancias de decisión regia, y fueron empleados como importantes activos en la ejecución de las misiones diplomáticas. A pesar de que las posibilidades de negociación de los miembros de las embajadas bajomedievales eran muy limitadas al tener que atenerse a los dictamentes del monarca registrados en poderes e instrucciones, se solía designar a personas de confianza que por su lealtad y su formación, generalmente coincidían con los miembros que trabajan en la alta administración del gobierno ${ }^{87}$.

Los eclesiásticos por el protagonismo activo en política exterior mantenido en el contexto del Gran Cisma de Occidente contaban con una enorme experiencia en asuntos diplomáticos ${ }^{88}$. Si a esta experiencia práctica, le añadimos una excelente formación ${ }^{89} \mathrm{en}$ derecho, retórica y latín; su prestigio ${ }^{90}$ y el valor legitimador de su juramento ${ }^{91}$, la importancia de la representación social del reino ${ }^{92}$, y sobre todo su fidelidad a la causa monárquica; hacen de los eclesiásticos un factor humano de indudable valor para la representación diplomática en todos los ámbitos.

El trabajo diplomático de los eclesiásticos en otros reinos occidentales se enmarcó dentro de sus labores dentro de la administración monárquica, como recursos económicos pero no por ello poco preparados ni carentes de lealtad a la causa de sus reyes, y fue muchas veces recompensado dentro de su carrera política y eclesiástica ${ }^{93}$. Por consiguiente, las etapas de mayor actividad de los eclesiásticos en embajadas siempre son coincidentes con una amplia participación de éstos en la administración del reino, aunque esta a su vez se puede relacionar con las necesidades de política exterior ante la influencia meditizadora del cisma. En el caso portugués es claramente palpable dentro de los cambios sufridos en la administración joanina, mientras en la primera etapa observamos como los eclesiásticos tuvieron un amplio papel en todos los órganos de poder y a su vez en las misiones diplomáticas, posteriormente en la segunda etapa percibimos lo contrario.

A continuación, analizaremos los tres escenarios de negociaciones diplomáticos en los que participaron decisivamente los eclesiásticos portugueses en pro de la legitimación de Juan I de Portugal y la dinastía Avis: la búsqueda del reconocimiento del pontífice romano (1385-1391), las negociaciones de las treguas con Castilla (1389-1411) y la participación en la solución conciliar (1409-1417). 


\subsection{Los eclesiásticos como embajadores en la búsqueda del reconocimiento del pontífice romano (1385-1391)}

31 monarca portugués, lo cual era especialmente interesante para conseguir eliminar los dos impedimentos que pesaban sobre su persona para poder ser un monarca legítimo y dispuesto a conformar una nueva dinastía: su condición de bastardo y su estatus religioso como maestre de Avis. Por ello, tras su proclamación como soberano de las cortes de Coimbra de 1385, Juan I de Portugal envió una delegación a la corte de Urbano VI conformada por João Eanes, obispo de Évora, y Gonçalo Gomes de Silva, que si bien obtuvo la dispensa del pontífice de forma oral, no pudo obtener su confirmación mediante bula papal. La crónica de Fernão Lopes lo achacó a la interferencia de un enviado inglés de Juan de Gante, duque de Lancaster, que en opinión del cronista defendió erróneamente los posibles derechos del duque sobre la corona portuguesa, en un momento donde Ricardo II de Inglaterra iba a establecer una alianza con la nueva dinastía portuguesa ${ }^{94}$.

egunda delegación fue enviada tres años después en $1388^{95}$, momento en el que había quedado clara la posición inglesa en torno a la dinastía Avis con el establecimiento de una alianza permanente mediante el Tratado de Windsor de $1386^{96} \mathrm{y}$ la cesión de cualesquier derechos que los Lancaster ingleses tuvieran sobre la corona portuguesa ${ }^{97}$. La embajada a la corte pontificia fue conformada por tres eclesiásticos: João Eanes, obispo de Évora, João Afonso Esteves de Azambuja, por aquel entonces todavía prior de Santa Maria da Alcáçova de Santarém, y Rodrigo Anes, canónigo de Lisboa. En esta ocasión la delegación volvió a repetir el fracaso de 1385, puesto que Urbano VI seguía negandose a conceder la ansiada bula, algo que en esta ocasión en la que el motivo político había desaparecido, se atribuyó a diferencias económicas. En la crónica de Fernão Lopes se retrató un enfrentamiento entre el pontífice y João Afonso Esteves de Azambuja, por el que el eclesiástico portugues le hizo saber su preocupación por la demora en la expedición de dicha bula, y finalmente cumplió la amenaza de retirarse. Parece que la cesión pontificia de la mitra algarvia a João Afonso Esteves de Azambuja fue una especie de premio de consolación al "impertinente" eclesiástico ${ }^{98}$. En la vuelta a territorio luso, la delegación fue apresada cuando atravesaban territorios alemanes $^{99}$, posiblemente como represalia a su atrevida actitud, lo que sin duda fue utilizado como prueba de su esfuerzo al servicio del monarca por parte de João Afonso Esteves de Azambuja, como podremos observar posteriormente en el reconocimiento de Juan I de Portugal cuando finalmente alcanzó a cumplir los objetivos regios.

El monarca portugués no desistió en su intento de obtener esa bula imprescindible para el reconocimiento de la nueva dinastía, y aprovechó el cambio de pontífice tras el fallecimiento de Urbano VI en 1389. Por consiguiente, se envió una nueva delegación a la corte de Bonifacio IX en 1390 compuesta por João Afonso Esteves de Azambuja, obispo de Silves, y el caballero João Rodrigues de Sá. La embajada se tradujo en un éxito rotundo con la obtención de las bulas Divina disponente clementia ${ }^{100}$ y Quia rationi congruit $^{101}$ de enero de 1391. Las bulas significaban la oficialización de la dispensa del anterior pontífice y ratificar la validez de la proclamación de Juan I de Portugal y de la celebración de su matrimonio con Filipa de Lancaster. Asimismo, también lograron que el papa absolviese de las penas en que incurrían todos los eclesiásticos que habían participado en armas, es decir, a todos los clérigos y prelados que combatieron en la 
guerra contra el Reino de Castilla, lo cual se había autorizado dada la condición de cismáticos de los castellanos ${ }^{102}$. Finalmente, consiguieron que los cismáticos que retornasen a la obediencia romana fuesen perdonados de las penas que recaían sobre ellos por parte de los decretos establecidos por Urbano $\mathrm{VI}^{103}$, algo que resultaba problemático en un reino como el de Portugal que había mudado varias veces de fidelidad, y que al mismo tiempo también resultaba provechoso para recuperar ese elemento propagandístico que eran los exiliados castellanos. El más importante de todos ellos fue el arzobispo compostelano Juan García Manrique, que tras ser derrotado en el enfrentamiento con el arzobispo toledano Pedro Tenorio por mediatizar la regencia de Enrique III de Castilla ${ }^{104}$, aceptó el acogimiento ofrecido por Juan I de Portugal en $1395^{105}$ y no tuvo reparos en declararse romanista, e incluso utilizar esta cuestión como excusa de su escapada al reino vecino. Las noticias sobre la trayectoria portuguesa de este eclesiástico son escasas y confusas, si bien se le atribuye la mitra bracarense entre 1398 y $1399^{106}$, solamente tenemos certeza de que haya ocupado la mitra conimbricense desde $1402^{107}$ hasta su muerte en $1404^{108}$.

Otra consecuencia a posteriori del establecimiento de unas buenas relaciones entre el reino de Portugal y el papado romano fue el otorgamiento en 1393 de la bula In eminentissimae dignitatis por la que todos los obispados que dependían de arzobispados castellanos: Lisboa, Évora, Lamego y Guarda (sufraganeas de Santiago de Compostela) y Silves (sufraganea de Sevilla), quedaban anexadas a un nuevo arzobispado de Lisboa ${ }^{109}$. De esta forma se sancionó la separación existente de facto entre las iglesias castellana y portuguesa.

La embajada de 1391 supuso para João Afonso Esteves de Azambuja el nombramiento como obispo de Oporto ${ }^{110}$, y también el reconocimiento de su monarca con la entrega del padroado de la iglesia de Salvador de Lisboa y la jurisdicción de la villa de Aveiras, como reconocimiento a sus "muitos e stremados serviços... specialmente como duas vezes, poendo seu corpo em aventura, foe por nosso embaxador a corte de Roma aderençar nosso fectos e negocios, que nos muito compriam, e aderençou segundo a nos fazia menester"111.

Esta primera misión diplomática trascendental para el futuro de la dinastía Avis supuso la utilización de dos recursos eclesiásticos de primera fila en la administración joanina, los consejeros João Eanes y João Afonso Esteves de Azambuja. El empleo de estos eclesiásticos era obligatorio al tratarse de una negociación con el papado, pero esta oportunidad no fue desaprovechada por João Afonso Esteves de Azambuja, cuyos méritos fueron reconocidos por su monarca y al que se le confiaron algunos de los negocios más importantes de la política exterior portuguesa: las negociaciones de paz con los castellanos y la participación portuguesa en los concilios que llevaron a la solución del Gran Cisma de Occidente.

\subsection{La participación de los eclesiásticos en la negociación de las treguas con los castellanos (1389-1411)}

La supervivencia de la nueva dinastía Avis dependía de dos factores en el contexto "internacional": una alianza permanente con el Reino de Inglaterra que sirviera de contrapeso a la amenaza castellana, y un tratado de paz con garantias con el Reino de 
Castilla. Consecuencia de ello se abrió un periodo de intensas relaciones diplomáticas en las que los eclesiásticos tuvieron una desigual participación, mientras que no tuvieron participación directa en los acuerdos con los ingleses, confiadas al sector anglófilo de la nobleza portuguesa representado en Fernão Afonso de Albuquerque, maestre de la orden de Santiago, y a Lourenço Anes de Fogaça ${ }^{112}$, sí tuvieron un papel destacado en la negociación de las diferentes treguas con los castellanos.

Los eclesiásticos no fueron protagonistas directos en las primeras negociaciones con los castellanos que derivaron en las treguas de Monção de $1389^{113}$, pero si estuvieron presentes en ellas dado que aparecen Lourenço Vicente, arzobispo de Braga, y João Eanes, obispo de Évora, como testigos del documento ${ }^{114}$. En cambio, en la renovación de esas treguas en $1392^{115}$ sí observamos la participación directa de Rui Lourenço, deán de Coimbra, hasta entonces el único eclesiástico con experiencia en cuestiones castellanas. $\mathrm{Su}$ aparición tiene lugar en la última fase de las negociaciones, no como embajador de los portugueses sino como testigo presencial de lo negociado ${ }^{116}$, lo que puede ser síntoma de que haya podido tener cierto protagonismo a la hora de desbloquear los acuerdos.

Un año más tarde el propio Rui Lourenço fue enviado por Juan I de Portugal ${ }^{117}$ para exigir al consejo de regencia Enrique III de Castilla, la entrega de un documento de ratificación de las treguas que cumpliese la cláusula de ser signado por todos los magnates más poderosos del reino, garantía exigida por el monarca portugués, consciente de las divisiones internas de la política castellana. A pesar de que los castellanos tenían de plazo hasta el mes de noviembre, la misión se dilató unos meses más en un intento de los regentes de obtener la suscripción de todos los nobles, intento que finalmente fracasó ante la negativa de Alfonso Enríquez de Noreña, conde de Noreña y de Gijón, y del marqués de Villena ${ }^{118}$. Rui Lourenço tras una estancia de cinco meses en la corte castellana, tuvo que regresar en marzo de 1393 con una ratificación que no cumplía todo lo requerido y con un documento de la cancillería castellana que justificaba el retraso ${ }^{119}$. Este hecho fue utilizado posteriormente por el monarca portugués para romper unilateralmente la tregua en 1396 e iniciar una campaña militar que tuvo su epicentro en la toma de Badajoz ${ }^{120}$, la cual era una respuesta al temor que causaba el fortalecimiento del vecino castellano ${ }^{121}$.

Las negociaciones para superar esta nueva situación de conflicto se abrieron en $1399^{122}$ y en ellas se designó como embajador portugués a João Afonso Esteves de Azambuja, por aquel entonces obispo de Oporto y célebre por el éxito en las misiones en el papado. Sin embargo, también se contó con Rui Lourenço en calidad de asesor jurídico ${ }^{123}$, probablemente para suplir la falta de experiencia del primero en asuntos castellanos. En esas negociaciones se produce un choque entre la estrella del "hombre nuevo" y el saber del "grande leterado" en las desavenencias en torno a las condiciones que se le tenían que exigir a los castellanos. João Afonso Esteves de Azambuja partidario de imponer mayores exigencias para alcanzar un acuerdo, informó a su monarca en una expresiva misiva con data el 28 de febrero de $1399^{124}$, que no apartó a Rui Lourenço por la intervención del otro embajador, el condestable Nuno Álvares Pereira ${ }^{125}$, y que informaría de sus actuaciones para que sean juzgados por ello. El monarca era consciente de tal situación y probablemente pensaba que si dos caracteres tan diferentes se ponían de acuerdo, siempre seria en pro de su reino. Por ello Juan I de Portugal impuso a João Afonso Esteves de Azambuja la presencia de Rui Lourenço hasta el final de la misión y exigió la unanimidad de los embajadores para tomar decisiones, 
tal y como atestigua una misiva redactada el 4 de diciembre de $1399^{126}$, hecho que coincidía con los últimos compases de unas negociaciones que resultaron ser un estrepitoso fracaso ante dos partes que no querían ceder un ápice en sus posiciones y que mantuvieron las escaramuzas fronterizas ${ }^{127}$. A pesar del fracaso, la participación de João Afonso Esteves de Azambuja en la negociación había sido recompensada con la mitra conimbricense, la misma sede en la que Rui Lourenço ejercía como deán, desde el comienzo de la misma. En el salvoconducto que le otorgó el monarca castellano para poder acudir a las negociaciones en mayo de 1399 , lo vemos por primera vez como obispo electo de Coimbra ${ }^{128}$, dignidad que ocupó plenamente en noviembre de $1399^{129}$.

Rui Lourenço falleció el 21 de julio de 1401 en Medina del Campo cuando se encaminaba a la corte regia de Enrique III, situada en ese momento en Segovia ${ }^{130}$, para acordar el retorno de las negociaciones. No se trataba de una embajada solemne, sino de una negociación puntual, de ahí que no se conservase testimonio alguno en crónicas y documentos de archivo, y conozcamos solamente la noticia de la muerte del deán en plena misión diplomática a través del asiento de su obiturario en el libro de aniversarias de la catedral de Coimbra ${ }^{131}$.

La embajada solemne para celebrar unas nuevas treguas de mayor entidad se celebró un año después ${ }^{132}$, todo ello a pesar de la oposición mostrada por el infante Fernando de Castilla en una carta dirigida a la delegación portuguesa ${ }^{133}$, que ya por aquel entonces tenía un protagonismo en la corte castellana. En abril de 1402, Juan I de Portugal apoderó a João Afonso Esteves de Azambuja, entonces obispo de Coimbra, junto a Juan Vázquez de Almada, caballero, y Martim do Sem, doctor en leyes ${ }^{134}$, para acudir a Segovia para negociar unas nuevas treguas, que finalmente se alcanzaron el 15 de agosto $^{135}$. Sin embargo, la misión se quedó en Castilla hasta el 6 de octubre esperando a que Enrique III de Castilla confirmase las treguas con el juramento de los principales personajes del reino ${ }^{136}$, para después estar presente el 18 de noviembre en la correspondiente confirmación de Juan I de Portugal con los juramentos debidos, la cual tuvo lugar en el palacio que el propio João Afonso tenía en Santarém ${ }^{137}$. Las negociaciones fueron un éxito rotundo, puesto que se logró una tregua que finalmente terminó siendo el punto y final a los enfrentamientos entre ambos reinos, cuestión que remarcó Fernão Lopes: "E d'esta guisa cessou entonce a guerra que entre Portugal e Castella havia"138. Para el exitoso João Afonso Esteves de Azambuja supuso ser nombrado arzobispado de Lisboa, si bien en el mencionado documento de poder de abril de 1402 aparece como postulante de Lisboa ${ }^{139}$, posteriormente figura como electo confirmado en el momento de su presencia en la confirmación de las treguas por el rey castellano ${ }^{140}$, pero por razones lógicas no pudo tomar posesión del arzobispado hasta su vuelta a Portugal en noviembre en el momento de la confirmación de las treguas por su propio monarca ${ }^{141}$.

43 En los años siguientes, el arzobispo de Lisboa fue responsable de los asuntos cotidianos que tenían que ver con el reino de Castilla. Por ejemplo, a finales de 1405 escribió a Diego López de Estúñiga para comunicarle que el monarca luso había dispuesto enviarle un escribano para tomar nota de sus reclamaciones de asaltos a sus navíos por parte de barcos portugueses ${ }^{142}$. Posteriormente, en agosto de 1407 vuelve a ser el protagonista de unas negociaciones diplomáticas con Castilla para renovar las treguas de 1402 ante la temprana muerte de Enrique III de Castilla y el inicio de una nueva problemática regencia en el Reino de Castilla ${ }^{143}$. Unas negociaciones en las que únicamente se acordó un aplazamiento de estas para agosto de $1408^{144}$, un nuevo encuentro que parece que 
nunca tuvo lugar ante el silencio de las fuentes. A pesar de que las treguas se mantuvieron de facto hasta el Tratado de paz de Ayllón de 1411, las divisiones en el consejo de regencia castellano entre la madre de Juan II de Castilla, Catarina de Lancaster, cercana a su hermana la reina portuguesa, y el tío de nuevo monarca, el infante Fernando, este último menos partidario de la negociación con el reino vecino ${ }^{145}$, impidieron alcanzar un nuevo acuerdo inmediato con los portugueses ${ }^{146}$. En el mencionado aplazamiento se requería que cada una de las dos delegaciones de la futura embajada debería estar compuesta por tres personas: un obispo o arzobispo, un caballero y un letrado. Una disposición basada en la costumbre que no fue seguida rigurosamente en la última fase de la construcción de las paces con Castilla (1411-1432), ya que ningún eclesiástico portugués volvió a participar en ella. Esto se debe a que dos factores: la pérdida de protagonismo de los eclesiásticos en la administración joanina y su ocupación en la larga serie de concilios celebrados para superar el Cisma de Occidente.

Desde entonces la única misión diplomática enviada por Juan I de Portugal a otro reino en la que participó un eclesiástico portugués fue la negociación del matrimonio del príncipe Duarte de Portugal con Leonor de Aragón en 1428, en la que Pedro de Noronha, arzobispo de Lisboa, tuvo un enorme protagonismo al estar relacionado con la futura princesa y reina de Portugal, al ser ambos descendientes de Enrique II de Castilla, fundador de la dinastía Trastámara ${ }^{147}$. Esta misma tendencia es la que se observa en los siguientes reinados, los eclesiásticos fueron apartados sistemáticamente de la diplomacia portuguesa con otros monarcas ${ }^{148}$, salvo algunas excepciones durante el reinado de Alfonso V de Portugal como las de João Galvão ${ }^{149}$ o Jorge da Costa ${ }^{150}$.

\subsection{Eclesiásticos portugueses como protagonistas en la solución conciliar (1409-1417)}

Los concilios celebrados con el objetivo de buscar una solución a la crisis del Gran Cisma Occidental, el primero fallido en Pisa (1409) y el segundo finalizado con éxito en Constanza (1414-1417), canalizaron los recursos eclesiásticos de la diplomacia portuguesa, puesto que eran recursos de obligado concurso al tratarse cuestiones de índole eclesiástica.

En este sentido, destaca la presencia de estos eclesiásticos en la delegación portuguesa del concilio de Pisa de 1409; la embajada estuvo capitaneada por el entonces experimentado João Afonso Esteves de Azambuja, arzobispo de Lisboa, acompañado de dos letrados de primer nivel como eran Lançarote Esteves y Diogo Martins, y de una serie de eclesiásticos de menor rango como eran Gonçalo Gonçalves, obispo de Lamego, el franciscano João Xira, confensor de Juan I de Portugal, y mestre Lorenço ${ }^{151}$; quienes no volveran a tener más protagonismo en otros concilios y en otras misiones diplomáticas. Los embajadores fueron los encargados de apoyar decididamente el nombramiento de Alejandro $\mathrm{V}$ tras el cambio de actitud del monarca portugués, que pasó de la neutralidad en la cuestión a intentar sacar réditos del apoyo a un nuevo pontífice pisano. Bajo el pontificado de su sucesor, Juan XXIII, se obtuvo la bula "Eximie Devocionis" el 20 de marzo de 1411 a petición de Juan I de Portugal que autorizaba a la corona lusa a ejercer la guerra justa contra los sarracenos ${ }^{152}$, la cual fue probablemente aquella que publicó el franciscano João de Xira ${ }^{153}$ en los prolegómenos de la conquista de Ceuta para legitimar la empresa que impulsó a la dinastía Avis en el contexto 
"internacional". Todo apunta a que la persona encargada de gestionar la obtención de esta bula fuese João Afonso Esteves de Azambuja ${ }^{154}$, que en junio de 1411 fue promocionado al cardenalato de Sancti Petri ad vincula ${ }^{155}$. De esta forma, Juan I de Portugal tuvo la suficiente legitimidad para iniciar esa campaña que ligaría a su dinastía con la defensa de la cristiandad y que le permitiría relegar al estamento eclesiástico a un segundo plano, cuestión que es visible desde la propia gestión de la campaña de Ceuta en la que los eclesiásticos no tuvieron protagonismo alguno ${ }^{156}$.

En las primeras sesiones del concilio de Constanza en 1414 se volvió a conformar otra embajada portuguesa liderada por el cardenal João Afonso Esteves de Azambuja, el cual estaba acompañado por Antão Martins de Chaves, deán de Évora, y un misterioso obispo de Oporto, que bien podría ser Fernando da Guerra ${ }^{157}$. El avezado eclesiástico llegó a presentarse en el concilio, pero falleció en Brujas a su regreso a Portugal en $1416^{158}$, por lo que tuvo que modificarse la composición de la delegación lusa y se incorporó a Vasco Peres, canónigo de Coimbra, junto con laicos como el doctor en leyes Gil Martins, desembargador y protector de la Universidad de Lisboa, y Fernando de Castro y Álvaro Fernandes de Ataíde, caballeros que habían participado en la conquista de Ceuta ${ }^{159}$. El concilio coincidió con la presentación del monarca portugués como nuevo cruzado de la cristandad, y este hecho que sirvió para que en los últimos compases antes del cierre del concilio, la delegación portuguesa pudiese plantear al recién nombrado Martín $\mathrm{V}$ una serie de peticiones como el reconocimiento de los derechos portugueses en las tierras que tomase a los sarracenos, la posibilidad de solicitar el subsidio de cruzada para proseguir las conquistas, y la creación de una diócesis en el nuevo territorio. Asimismo, también solicitó que el nuevo pontífice dispensase a todos sus hijos para poder iniciar una política matrimonial destinada a garantizar la supervivencia de la dinastía Avis, una disposición que realmente estaba dirigida a su hijo Enrique el Navegante, quien iba a ser nombrado maeste de la orden de Cristo ${ }^{160}$. El nuevo pontífice en respuesta le concedió una bula de cruzada Rex Regum por la que le concedió indulgencia plenaria y la predicación de cruzada para todas las empresas portuguesas contra los sarracenos ${ }^{161}$; y la bula Romanus Pontifex por la que se autorizaba la erección de una catedral en Ceuta ${ }^{162}$.

A partir de entonces se abre una intensa línea diplomática entre el monarca portugués y el nuevo pontífice entre 1418 y 1426 en la que Juan I de Portugal fue arrancando diversos privilegios en torno a los intereses norteafricanos y canarios, o sobre el estatus de su hijo Enrique el Navegante ${ }^{163}$. En estas pequeñas misiones se emplearon recursos diplomáticos eclesiásticos como el mencionado Antão Martins de Chaves, entonces obispo de Oporto desde $1423^{164}$, o Pedro de Noronha, obispo de Évora en $1419^{165}$ y arzobispo de Lisboa en $1424^{166}$, los cuales las utilizaron para catapultar sus correspondientes carreras eclesiásticas.

49 Como hemos observado la actuación portuguesa en los concilios tuvo como objetivo la defensa de los intereses dinásticos, donde se apoyaron determinadas soluciones siempre con miras a la obtención de prebendas que legitimasen la nueva política exterior de la corona portuguesa como defensora del cristianismo ultramar, un objetivo en el que los eclesiásticos designados por el monarca actuaron como meros peones de sus intereses. 


\section{Conclusiones}

50 El elemento eclesiástico fue fundamental en la legitimación de la nueva dinastía portuguesa Avis, tanto en el ámbito interior como en la política exterior. Los eclesiásticos que fueron promocionados por la defensa de la causa urbanista encarnada en la figura del maestre de Avis, bien como "hombres nuevos" o bien cambiando su servicio al nuevo candidato, se convirtieron en recursos humanos de gran potencialidad para la diplomacia de Juan I de Portugal. Los eclesiásticos contaban con una enorme experiencia en asuntos de administración, participando en el consejo real y en el desembargo regio, y también en diplomacia, en una época de enorme actividad exterior derivada del Gran Cisma de Occidente. Asimismo, se debe de tener en cuenta de que eran recursos humanos con una excelente formación, sobre todo en derecho civil y canónico, en un contexto en el que los jurisconsultos laicos no eran abundantes. Asimismo, por su condición resultaban fundamentales ideológicamente para sancionar cuestiones como la obtención de prebendas papales, la aportación en las sesiones conciliares, la construcción de una paz entre reinos cristianos (la pax cristiana), o la celebración de matrimonios; todas ellas fundamentales para los objetivos de supervivencia y legitimación en la política externa de la dinastía Avis.

51 No obstante, los eclesiásticos eran recursos finitos que no podían abarcar toda la enorme amplitud de la política exterior joanina, siendo la prioridad todo lo relacionado con la cabeza de la Iglesia, por ello cuando estaban negociando el reconocimiento inicial del papado romano (1385-1391), desaparecieron de algunos ámbitos como las negociaciones del Tratado de Windsor de 1386 con el Reino de Inglaterra o en las primeras compases de la pacificación con los castellanos, las Treguas de Monção de 1389; o en el momento de elaborar la solución conciliar (1409-1418) y obtener prebendas de Martín V (1417-1431), se ausentaron de la celebración de las paces con los castellanos en Ayllón en 1411 y su posterior ratificación en 1423, o en Medina del Campo en 1433. Al mismo tiempo debemos tener en cuenta de que en la segunda parte del reinado de Juan I de Portugal hubo una marginación sistemática del elemento eclesiástico en la administración joanina derivada del rumbo regalista que había tomado el gobernante luso tras haber logrado su legitimación, lo que reducirá aun más si cabe la cantidad de recursos eclesiásticos disponibles para la diplomacia portuguesa.

Los eclesiásticos defendieron con ahinco los intereses de la monarquía, aunque siempre mediatizados por la búsqueda de una contrapartida en forma de beneficios eclesiásticos, ésto se observa especialmente en la trayectoria de eclesiásticos como João Afonso Esteves de Azambuja en el que cada misión se traducía directamente con un ascenso en la Iglesia, desde el priorato de Santa Maria da Alcáçova de Santarém hasta el cardinalato de Sancti Petri ad vincula, pasando por diferentes mitras portuguesas tales como Silves, Oporto, Coimbra o Lisboa. Aunque en otros casos no había una correspondencia tan evidente como es el caso de Rui Lourenço, por lo que podemos entrever la posible existencia de servidores del estado, o al menos, de la dinastía.

Con todo, los eclesiásticos fueron un elemento imprescindible para la consecución de los objetivos en política exterior encaminados a la consolidación de la dinastía Avis, teniendo un protagonismo incluso más importante que lo conocido en situaciones similares de surgimiento de nuevas dinastías europeas en contextos de ilegitimidad como puede ser el caso de los Trastámaras castellanos ${ }^{167}$. Prueba de la estrecha vinculación entre la colaboración del estamento eclesiástico y la legitimación del 
empoderamiento de las monarquías en el occidente medieval que pretendimos dilucidar en el proyecto "La dimensión europea de un grupo de poder: el clero y la construcción política de las monarquías ibéricas entre los siglos XIII y XV" en el que se enmarca este trabajo.

\section{BIBLIOGRAFÍA}

1. Fuentes manuscritas

Archivo Secreto Vaticano (ASV)

Obligationes: registro 48A, fols. 101r. y 110r.; registro 57, fol. 35 .

Obligationes et Solutiones: registro 48, fol. 152v.; registro 51, fols. 20v. y 66r.

Registra Lateranensia: registro 12, fols. 10v.-12v., 40r.-41r., 64v.-65r.; registro 17, 47r.; registro 29, fols. 188r.-188v.; registro 32, 131r.; registro 195, 289r.; registro 233, 301r.

Registra Supplicationum, registro 110, fol. 178r.; registro 145, fol. $145 \mathrm{r}$.

Registra Vaticana, registro 352, fol.153v.

Biblioteca Apostolica Vaticana (BAV)

Barberiniani latini: códice 872, fol. 99r-104r.

Arquivo Nacional da Torre do Tombo (ANTT)

Bulas: maço 5, documento 9; maço 11, documento 13; maço 26, documento 15.

Cabido da Sé de Coimbra: livro 5 (livro das calendas 2), 81v.; $2^{\underline{a}}$ Incorporação, maço 94, documento 4498.

Chancelaria de D. João I: livro 2, fols. 45r.-45v. y 91v.-92r.

Gavetas: gaveta 14, maço 1, documento 20, fols. 3v-10r.; gaveta 17, maço 4, documento 8; gaveta 17 , maço 6 , documentos 7, 10, 11 y 16; gaveta 18 , maço 3, documentos 25 y 26 ; gaveta 18 , maço 11 , documento 4 .

Leitura Nova: livro 38 (Livro I dos Reis), fols. 8r.-9v.; livro 61 (Livro das pazes), fol. 142r.-165r.

Manuscritos: número 364, fol. 457r.

Arquivo da Casa da Moeda de Lisboa (ACML)

Livro dos moedeiros, fol. $2 \mathrm{v}$.

Arquivo Histórico da Câmara do Porto (AHMP)

Livro B, fols. 302-308v.

Vereações: livro 2, fol. 47v.

Archivo General de Simancas (AGS)

Patronato Regio: legajo 47, documentos 27, 29.4, 30, 31, 32, 33 y 34; legajo 49, documentos 1, 3, 4, 7, $8,9,10,14,15$ y 53 
Estado, Castilla: legajo 1-1ํ, fol. 86.

Archivo General de la Corona de Aragón (ACA)

Cancillería Real: Registro 1256, fol. 188r.; Registro 2692, fols. 13v.-19v.

D. Fernando I, caja 12, documento 2120 .

British Museum of London (BML)

Biblioteca Cotton, Nero, B. I., fol. 41r.

Archivio di Stato di Bologna (ASB)

Liber secretus iuris cesarei ab anno 1378 ad annum 1512, fol. 6v.

Rogiti di Paolo Cospi, busta protoc. 16, fol. 37v.

2. Fuentes impresas

As Gavetas da Torre do Tombo. Vol. 1, 2, 7, 8, 9. Lisboa: Centro de Estudos Históricos Ultramarinos, 1960-1971.

CARRILLO DE HUETE, Pedro - Crónica de Pedro Carrillo de Huete, halconero de Juan II de Castilla. Ed. Juan de Mata Carriazo. Madrid: Espasa-Calpe, 1946.

COSTA, António Domingues de Sousa - Monumenta Portugaliae Vaticana. Vol. 2. Roma-Braga: Livraria Editorial Franciscana, 1970.

Liber anniversariorum ecclesiae cathedralis colimbriensis: livro das kalendas. Ed. Pierre David y Torquato da Sousa Soares, Vol. 2. Coimbra: Universidade de Coimbra, 1947.

LOPES, Fernão - Chronica de el-rei D. Fernando. Ed. Luciano Cordeiro. Vol. 2 e 3. Lisboa: Escriptorio, $1895-1896$

LOPES, Fernão - Chronica de el-rei D. João I. Ed. Luciano Cordeiro. Vol. 2-7. Lisboa: Escriptorio, 1897-1898.

LÓPEZ DE AYALA, Pedro - Crónica de Enrique III. in Crónicas de los reyes de Castilla. Ed. Eugenio Llaguno Amirola. Vol. 1: Crónicas de Pedro I, Enrique II, Juan I y Enrique III. Madrid: Imprenta de Don Antonio de Sancha, 1779.

Monumenta Henricina. Ed. A. J. Dias Dinis. Vol. 1-3. Coimbra: Comissão Executiva das Comemorações do V Centenário da Morte do Infante D. Henrique, 1960-1961.

PIANA, Celestino - Nuovi documenti sull'Università di Bologna e sul Collegio di Spagna. Vol. 1. Bolonia: Publicaciones del Real Colegio de España, 1976.

PRATI, Ludovico - Chartularium Studii Bononiensis. Vol. 4. Bologna: Commisione per la Storia dell’Università di Bologna, 1919.

SÁ, Artur Moreira de (ed.) - Chartularium Universitatis Portugalensis (1288-1537). Vol. 2: 1377-1408. Lisboa: Instituto de Alta Cultura, 1968.

SANTARÉM, Visconde de - Quadro elementar das relações politicas e diplomaticas de Portugal com as diversas potencias do mundo, desde o principio da monarchia portugueza ate aos nossos dias. Vol. 1, 3, 8, 14. París: J. P. Aillaud, 1842-1865.

SILVA, Manuel Telles de - Collecçam dos documentos e memorias da Academia Real da Historia Portuguesa. Lisboa: Oficina de Pascual de Silva, 1724.

SYLVA, Joseph Soares de - Memorias para a História de Portugal que comprehendem o governo delrey D. João I. Vol. 2. Lisboa: Officina de Joseph Antonio da Sylva, 1730. 
SORBELLI, Albano (ed.) - Liber secretus iuris cesarei dell'Universitá di Bologna. Vol. 1: 1378-1420. Bolonia: Università di Bologna, 1938

SUÁREZ FERNÁNDEZ, Luis; TORRE, Antonio de la - Documentos referentes a las relaciones con Portugal durante el reinado de los Reyes Católicos. Vol. 1. Valladolid, 1958.

ZURARA, Gomes Eanes de - Crónica da Tomada de Ceuta. Ed. Francisco Maria Esteves Pereira. Lisboa: Academia das Sciencias de Lisboa, 1915.

3. Bibliografia / Estudos

ALMEIDA, Fortunato - História da Igreja em Portugal. Vol. 2. Porto: Editorial Portucalense, 1967.

ÁLVAREZ PALENZUELA, Vicente - "Relations between Portugal and Castile in the Late Middle Ages - 13th-16th centuries". E-Journal of Portuguese History 1/1 (2003).

ÁLVAREZ PALENZUELA, Vicente - "El restablecimiento de la paz entre Castilla y Portugal: 1402-1431". in COSTA, Paula Maria de Carvalho Pinto; HOMEM, Armando Luis de Carvalho; PIZARRO, José Augusto de Sotto Mayor (eds.) - Ibéria, quatrocentos/quinhentos, duas décadas de cátedra (1984-2006): homenagem a Luís Adão da Fonseca. Porto: CEPESE, 2009, pp. 47-90.

ARÁUJO, Julieta - Portugal e Castela na Idade Média. Lisboa: Edições Colibri, 2009.

ARNAUT, Salvador Dias - A crise nacional dos fins do século XIV. Vol. 1: A sucessão de D. Fernando. Coimbra: Universidade de Coimbra, 1960.

BABO, Duarte - Os embaixadores portugueses nos reinos ibéricos (1431-1474): um estudo sociodemográfico. Porto: Universidade do Porto, 2017. Tese de Doutoramento.

BAEZA HERRATZI, Alberto - Bulas de cruzada en la reconquista de Ceuta. Ceuta: Caja de ahorros y monte de piedad de Ceuta, 1987.

BAPTISTA, Julio - “Portugal e o Cisma de Ocidente”. Lusitania Sacra 1 (1956), pp. 65-203.

BECEIRO PITA, Isabel - “Las negociaciones entre Castilla y Portugal en 1399”. Revista da Faculdade de Letras da Universidade do Porto: História (Série II) 13 (1996), pp. 149-185.

BECEIRO PITA, Isabel - "La consolidación del personal diplomático entre Castilla y Portugal, 1392-1455”. in GONZÁLEZ JIMÉNEZ, Manuel (ed.) - La Península Ibérica en la era de los descubrimientos 1391-1492, Actas de las III Jornadas Hispano-Portuguesas de Historia Medieval. Vol. 2. Sevilla: Consejería de Cultura de la Junta de Andalucía, 1997, pp. 1735-1744.

BRÁSIO, António - “Erecção da Metrópole Lisbonense”. Lusitania Sacra 2 (1957), pp. 51-56.

COELHO, André Madruga - "Ecclesiastical Support to the Master of Avis: An Analysis from the Aclamation Act of 1385”. En la España Medieval 40 (2017), pp. 147-162.

COELHO, Maria Helena da Cruz - D. João I: o que re-colheu Boa Memória. Mem Martins : Círculo de Leitores, 2005.

CONTAMINE, Philippe - “Le moyen âge occidental a-t-il connu des serviteurs de l'état?". in Les serviteurs de l'état au moyen âge. Actes du 29e congrês de la Societé des historiens médiévistes de l'enseigneiment supérieur public. Pau: Publications de la Sorbonne, 1998, pp. 9-20.

COSTA, António Domingues de Sousa - Monumenta Portugaliae Vaticana. Vol. III/1: A Península Ibérica e o Cisma de Ocidente, repercussão do cisma na nacionalidade portuguesa do século XIV e XV. Roma-Braga: Livraria Editorial Franciscana, 1982. 
COSTA, António Domingues de Sousa - “D. João Afonso de Azambuja, cortesão, bispo, arcebispo, cardeal e fundador do convento das dominicanas do Salvador de Lisboa". Arquivo Histórico Dominicano Português 4/2 (1989), pp. 1-150.

COSTA, António Domingues de Sousa - Portugueses no Colégio de S. Clemente e Universidade de Bolonha durante o século XV. Vol. 1. Bolonha: Publicaciones del Real Colegio de España, 1990.

COSTA, Avelino de Jesus da - "A biblioteca e o tesouro da Sé de Coimbra nos séculos XI a XVI". Boletim da Biblioteca da Universidade de Coimbra 38 (1983), pp. 1-220.

CUNHA, Maria Cristina; FREITAS, Judite - "Homens de estado, crises políticas e guerra: Portugal, séculos XIV-XV”. in COELHO, Maria Helena da Cruz; GOMES, Saul António; REBELO, António Manuel Ribeiro (coords.) - A guerra e a sociedade na Idade Média. VI Jornadas Luso-Espanholas de Estudos Medievais. Vol. 2. Coimbra: Sociedade Portuguesa de Estudos Medievais, 2009, pp. 121-139. CUNHA, Rodrigo da - Historia ecclesiastica dos arcebispos de Braga. Vol. 2. Braga: Imprenta Manoel Cardozo, 1635.

CUNHA, Rodrigo da - Catálogo dos bispos do Porto (Segunda impressam addicionado e com supplementos de varias memorias ecclesiasticas). Vol. 2. Porto: Oficina prototypa episcopal, 1742.

DÍAZ MARCILLA, Francisco José - "El papel del clero en el cambio dinástico en Portugal (1378-1388)". Reti Medievali 19/2 (2018), pp. 131-170.

DÍAZ MARCILLA, Francisco José - "El clero en el contexto diplomático de la Guerra de los Cien Años: una mirada desde las crónicas oficiales al período ibérico (1366-1388)”. in VIGIL MONTES, Néstor (dir.) - Comunicación política y diplomacia en la Baja Edad Media. Évora: Publicações do CIDEHUS, 2019, pp. 47-74.

DÍAZ MARTÍN, Luis Vicente - "Los inicios en política internacional de Castilla (1360-1410)". in RUCQUOI, Adeline (coord.) - Realidad e imágenes de poder. España a fines de la Edad Media. Valladolid: Ámbito Ediciones, 1988, pp. 57-83.

DUARTE, Luis Miguel - Ceuta 1415, seiscentos anos depois. Lisboa: Livros Horizonte, 2015.

EUBEL, Konrad - Hierarchia Catholica Medii Aevi. Vol. 1. Ratisbona: Monasterii Sumptibus et typis librariae Regensbergianae, 1913.

FARELO, Mário - A oligarquia camarária de Lisboa (1325-1433). Lisboa: Universidade de Lisboa, 2009. Tese de doutoramento.

FARELO, Mário - "La représentation de la couronne portugaise à Avignon et ses agents (1305-1377)". Anuario de Estudios Medievales 40/2 (2010), pp. 723-763

FARIA, Tiago Viúla de - "Por proll e serviço do reino? O desempenho dos negociantes portugueses do Tratado de Windsor e suas consequências nas relações com Inglaterra". in COELHO, Maria Helena da Cruz; GOMES, Saul António; REBELO, António Manuel Ribeiro (coords.) - A guerra e a sociedade na Idade Média. VI Jornadas Luso-Espanholas de Estudos Medievais. Vol. 2. Coimbra: Sociedade Portuguesa de Estudos Medievais, 2009, pp. 209-227.

FILHO, Franklin Manuel Tavares - “Os Portugueses no Concílio de Constança (1416-1418): Questões e Problemas”. Plêthos 4/1 (2014), pp. 187-203.

FONSECA, Luis Adão de - O essencial sobre o Tratado de Windsor. Lisboa: Imprensa Nacional - Casa da Moeda, 1986.

FONSECA, Luis Adão de - "Significado da Batalha de Aljubarrota no contexto da conjuntura política europeia no último quartel do século XIV”. in COELHO, Maria Helena da Cruz; GOMES, Saul António; REBELO, António Manuel Ribeiro (coords.) - A guerra e a sociedade na Idade Média. VI 
Jornadas Luso-Espanholas de Estudos Medievais. Vol. 1. Coimbra: Sociedade Portuguesa de Estudos Medievais, 2009, pp. 57-74.

FONTES, João Luís Inglês - “João Afonso Esteves de Azambuja (1402-1415)”. in FONTES, João Luís Inglês (ed.) - Bispos e arcebispos de Lisboa. Lisboa: Livros Horizonte, 2018, pp. 471-484.

GENET, Jean-Philippe - “Le coup d'État ou les légitimités contrariées”. in FORONDA, François; GENET, Jean-Philippe; NIETO SORIA, José Manuel (eds.) - Coups d'État à la fin du Moyen Âge? Aux fondements du pouvoir politique en Europe occidentale, Madrid: Casa de Velázquez, 2005, pp. 1-17.

GOMES, Rita Costa - The Making of a Court Society. Kings and Nobles in Late Medieval Portugal. Cambridge: Cambridge University Press, 2003.

GOMES, Saul António - "Três bibliotecas particulares na Coimbra de Trezentos, em torno das elites e das culturas urbanas medievais”. Revista de História das Ideias 24 (2003), pp. 9-49.

GONZÁLEZ SÁNCHEZ, Santiago - Las relaciones exteriores de Castilla a comienzos del siglo XV. La minoría de Juan II (1407-1420). Madrid: Comité Español de Ciencias Históricas, 2013, pp. 134-142.

GRAF, Carlos Eduardo de Verdier - D. João Esteves da Azambuja: exemplo da interligação de poderes (séculos XIV e XV). Porto: Universidade do Porto. 2011. Dissertação de Mestrado.

GROHE, Johannes - "Spanien und die großen Jonzilien von Konstanz und Basel”. In HERBERS, Klaus, JASPERT, Nikolas (ed.) - "Das kommt mir spanisch vor" - Eigenes und Fremdes in den deutschspanischen Beziehungen des späten Mittelalters. Münster: LIT Verlag, 2004, pp. 493-509.

GUENÉE, Bernard - Occidente durante los siglos XIV y XV, los estados. Barcelona: Labor, 1973.

HOMEM, Armando Luís de Carvalho - "O doutor João das Regras no desembargo e no conselho régios (1384-1404). Breves notas". in Estudos de história de Portugal, Homenagem a A. H. de Oliveira Marques. Vol. 1: séculos X-XV. Lisboa: Estampa, 1982. pp. 241-253.

HOMEM, Armando Luís de Carvalho - O desembargo régio: 1320-1433. Porto: Instituto Nacional de Investigação Cientifica. Centro de História da Universidade do Porto, 1985.

HOMEM, Armando Luís de Carvalho - "Diplomacia e diplomatas nos finais da Idade Média: a propósito de Lourenço Anes Fogaça, chanceler-mor (1374-99) e negociador do Tratado de Windsor". in Colóquio comemorativo do VI Centenário do Tratado de Windsor. Porto: Universidade do Porto, 1986. pp. 221-240.

HOMEM, Armando Luís de Carvalho - "Conselho real ou conselheiros do rei? A propósito dos privados de D. João I”. Revista da Faculdade de Letras da Universidade do Porto: História (Série II) 4 (1987), pp. 9-68.

LEITÃO, André de Oliveira - "Leges et canones. Portuguese law students in 14th and 15th century Italy. Methodological horizons and problems". in VILAR, Hermínia; BRANCO, Maria João (Eds.) Ecclesiastics and political state building in the Iberian monarchies, 13th-15th centuries, Évora: Publicações do CIDEHUS, 2016, pp. 275-290.

MARQUES, António Henrique de Oliveira - Nova História de Portugal. Direcção de Joel Serrão e António Henrique de Oliveira Marques. Vol. 4: Portugal na crise dos séculos XIV e XV. Lisboa: Editorial Presença, 1989.

MARQUES, José - "Legislação e práctica judicial como fontes de tensões entre D. João I e a Igreja”. Revista de História 10 (1990), pp. 9-34.

MARQUES, José - "Relações entre a Igreja e o Estado em Portugal, no século XV". Revista da Faculdade de Letras da Universidade do Porto: História (Série II) 11 (1994), pp. 137-172. 
MARQUES, José - "O senhorio de Braga no século XV: principais documentos para o seu estudo". Bracara Augusta 46 (1997), pp. 5-136.

MATTOSO, José - “Lutas de classes?”. in SARAIVA, José Hermano (dir.) - História de Portugal. Vol. 3. Lisboa: Publicaciones Alfa, 1983, pp. 193-199.

MAZZETTI, Serafino - Repertorio di tutti i professori antichi e moderni della famosa Università e del célebre istituto delle scienze di Bologna. Bolonia: Arnaldo Forni Editore, 1988.

MENDONÇA, Manuela - D. Jorge da Costa, cardeal de Alpedrinha. Lisboa: Edições Colibri, 1991.

MILLET, Hélène - "La participation de Portugal au Concile de Pise (1409)". in A igreja e o clero português no contexto europeu. Lisboa: Centro de Estudos de História Religiosa da Universidade Católica Portuguesa, 2005, pp. 233-254.

MITRE FERNÁNDEZ, Emilio - “Notas sobre la ruptura castellano-portuguesa de 1396”. Revista Portuguesa de História 12 (1969), pp. 213-221.

MOEGLIN, Jean-Marie; PÉQUIGNOT, Stéphane - Diplomatie et "relations internationales" au Moyen Âge (IXe-XVe siècle). París: Publications Universitaires de France, 2017.

MONTOJO JIMÉNEZ, Carlos - La diplomacia castellana bajo Enrique III, estudio especial de la embajada de Ruy González de Clavijo a la corte de Tamerlán. Madrid: Escuela Diplomática, 2004 (1944).

MUHAJ, Ardian - Portugal e a Coroa de Aragão nos séculos XIV-XV. A guerra dos Cem Anos e a sua influência na decadência da Catalunha e na expansão de Portugal. Lisboa: Universidade de Lisboa, 2006. Dissertação de Mestrado.

NIETO SORIA, José Manuel - Iglesia y génesis del estado moderno en Castilla (1369-1480). Madrid: Editorial Complutense, 2009.

OLAVO, Carlos - João das Regras, jurisconsulto e homem de estado. Guimarães: Lisboa: Livraria Editora Guimarães e C ${ }^{\mathrm{a}}, 1941$.

OLIVEIRA SERRANO, César - Beatriz de Portugal, la pugna dinástica Avis-Trastámara. Santiago de Compostela: Instituto de Estudios Gallegos Padre Sarmiento, 2005.

PÉQUIGNOT, Stephane - Au nom du roi: practique diplomatique et pouvoir durant le règne de Jacques II d'Aragon, 1291-1327. Madrid: Casa de Velázquez, 2009.

PEREIRA, Reina Marisol Troca - Discursos dos embaixadores portugueseses no Concílio de Constança: 1415. Coimbra: Universidade de Coimbra, 1999. Dissertação de mestrado.

PERES, Damião - História dos moedeiros de Lisboa como classe privilegiada. Vol. 1. Lisboa: Academia Portuguesa da História, 1964.

PIMENTA, Alfredo - “As treguas de Monção de 1389”. in Idade-Média (Problemas \& soluçõens). Lisboa: Edições Ultramar, 1946. pp. 317-328.

RIBEIRO, Luís Mário Araújo - A transição do senhorio episcopal portucalense para a Coroa em 1406. Porto: Universidade do Porto, 2009. Dissertação de mestrado.

RUSSELL, Peter Edward - The English intervention in Spain and Portugal in the time of Edward III and Richard II. Oxford: Clarendon Press, 1955.

SÁNCHEZ HERRERO, José - "Los obispos castellanos y su participación en el gobierno de Castilla, 1350-1406". in RUCQUOI, Adeline (coord.) - Realidad e imágenes de poder. España a fines de la Edad Media. Valladolid: Ámbito Ediciones, 1988, pp. 85-114. 
SÁNCHEZ SESA, Rafael - "El Cisma de Occidente en la Península Ibérica: religión y propaganda en la guerra castellano-portuguesa". in Estudos em homenagem ao professor doutor José Marques. Vol. 4. Porto: Universidade do Porto, 2006, pp. 307-320.

SANTOS, Maria Alice Pereira - A sociología da representação político-diplomática no Portugal de D. João I. Lisboa: Universidade Aberta, 2015. Tese de doutoramento.

SILVA, Nuno Espinosa Gomes da - "João das Regras e outros juristas portugueses da Universidade de Bolonha (1378-1421)". Revista da Faculdade de Direito da Universidade de Lisboa 12 (1960). pp.

223-253.

SOUSA, Armindo de - As cortes medievais portuguesas: 1385-1490. Vol. 1-2. Lisboa: Instituto Nacional de Investigação Científica, 1990.

SUÁREZ FERNÁNDEZ, Luis - Castilla, el cisma y la crisis conciliar (1378-1440). Madrid: Consejo Superior de Investigaciones Científicas, Escuela de Estudios Medievales, 1960.

SUÁREZ FERNÁNDEZ, Luis - Relaciones entre Portugal y Castilla en la época del infante don Enrique. Madrid: Consejo Superior de Investigaciones Científicas, Escuela de Estudios Medievales, 1960.

VEAS ARTESEROS, Francisco de Asís - Itinerario de Enrique III. Murcia: Universidad de Murcia, 2003.

VENTURA, Margarida Garcez - Igreja e poder no século XV. Dinastia de Avis e liberdades eclesiásticas (1383-1450). Lisboa: Edições Colibri, 1997.

VIGIL MONTES, Néstor - "João Afonso Esteves de Azambuja y Rui Lourenço, dos perfiles de eclesiástico diferentes en los primeros compases de la construcción de las paces entre Portugal y Castilla (1389-1407)". in VILAR, Hermínia; BRANCO, Maria João (eds.) - Ecclesiastics and political state building in the Iberian monarchies, 13th-15th centuries, Évora: Publicações do CIDEHUS, 2016, pp. 129-146.

VIGIL MONTES, Néstor - "Un eclesiástico para un reinado: el servicio del obispo conimbricense João Galvão a D. Afonso V de Portugal”. Lusitania Sacra 35 (2017), pp. 185-206.

VIGIL MONTES, Néstor - "Cuestiones metodológicas acerca del rol de los eclesiásticos en la formación de la diplomacia de las monarquías europeas en la Baja Edad Media”. Vegueta, Anuario de la Facultad de Geografía e Historia de la Universidad de las Palmas de Gran Canaria 18 (2018), pp. 403-423.

VIGIL MONTES, Néstor - "Pedro de Noronha (1423-1452)”. in FONTES, João Luís Inglês (ed.) Bispos e arcebispos de Lisboa. Lisboa: Livros Horizonte, 2018, pp. 495-501.

VIGIL MONTES, Néstor - "Eclesiásticos en la construcción política de una nueva dinastía: los clerici regis de la primera generación de la administración de Juan I de Portugal (1385-1415)". eHumanista 43 (2019), pp. 89-106.

VILAR, Hermínia Vasconcelos - As dimensiões de um poder, a diocese de Évora na Idade Média. Lisboa: Editorial Estampa, 1999.

VILAR, Hermínia Vasconcelos - "Na sombra da crise de 1383-85: o governo do bispo D. João de Évora”. Eborensia 39-40 (2008), pp. 103-116.

VILAR, Hermínia Vasconcelos - "Bispos na conquista de Ceuta ou os possiveis significados de uma ausência”. in COELHO, Maria Helena da Cruz; HOMEM, Armando Carvalho (coords.) - As décadas de Ceuta (1385-1460). Lisboa: Caleidoscópio e Universidade Autónoma de Lisboa Luís de Camões, 2018, pp. 93-108. 
VILLARROEL GONZÁLEZ, Óscar - "Eclesiásticos en la diplomacia castellana en el siglo XV". Anuario de Estudios Medievales 40/2 (2010), pp. 791-819.

WITTE, Charles-Martial de - Les bulles pontificales et l'expansion portugaise au XVe siècle. Lovaina la Nueva: Université catholique de Louvain, 1958.

\section{NOTAS}

1. El término "golpe de estado" ha sido utilizado de forma anacrónica por los medievalistas para referirse a los diversos cambios dinásticos producidos en el periodo bajomedieval, en los cuales un candidato alternativo lograba suplantar al monarca legítimo y establecer una nueva dinastía. GENET, Jean-Philippe - "Le coup d'État ou les légitimités contrariées". in FORONDA, François; GENET, Jean-Philippe; NIETO SORIA, José Manuel (eds.) - Coups d'État à la fin du Moyen Âge? Aux fondements du pouvoir politique en Europe occidentale. Madrid: Casa de Velázquez, 2005, pp. 1-17. La cuestión de los cambios dinásticos y la legitimidad fue objeto de debate más recientemente en dos congresos celebrados en Lisboa en 2015, uno de ellos tuvo por título Kings and Queens 4: Dynastic changes and Legitimacy, y el otro Debuerit habere regnum: Deponer y proclamar reyes en la Edad Media. Cabe destacar que algunos de los trabajos presentados en este último congreso fueron publicados en el número 23 de la revista Medievalista online.

2. El término internacional se tiene que utilizar de forma anacrónica para describir las implicaciones que tuvo el ascenso al trono de la dinastía Avis en otras formaciones políticas de su entorno, es decir, del Occidente Medieval Europeo. Por ello nos hemos decantado por entrecomillarlo, así como han hecho Stéphane Péquignot y Jean-Marie Moeglin en su reciente manual sobre diplomacia y "relaciones internacionales" en la Edad Media. MOEGLIN, Jean-Marie; PÉQUIGNOT, Stéphane - Diplomatie et "relations internationales" au Moyen Âge (IXe-XVe siècle). Paris: Publications Universitaires de France, 2017.

3. FONSECA, Luis Adão de - "Significado da Batalha de Aljubarrota no contexto da conjuntura política europeia no último quartel do século XIV". in COELHO, Maria Helena da Cruz; GOMES, Saul António; REBELO, António Manuel Ribeiro (coords.) - A guerra e a sociedade na Idade Média. VI Jornadas Luso-Espanholas de Estudos Medievais. Vol. 2. Coimbra: Sociedade Portuguesa de Estudos Medievais, 2009, pp. 57-74.

4. MATTOSO, José - “Lutas de classes?". in SARAIVA, José Hermano (dir.) - História de Portugal. Vol. 3. Lisboa: Publicaciones Alfa, 1983, pp. 193-199.

5. Las relaciones luso-castellanas durante el reinado de D. João I de Portugal han sido analizadas por diversos autores. SUÁREZ FERNÁNDEZ, Luis - Relaciones entre Portugal y Castilla en la época del infante don Enrique. Madrid: Consejo Superior de Investigaciones Científicas, Escuela de Estudios Medievales, 1960. ARÁUJO, Julieta - Portugal e Castela na Idade Média. Lisboa: Edições Colibri, 2009. ÁLVAREZ PALENZUELA, Vicente - "El restablecimiento de la paz entre Castilla y Portugal: 1402-1431". in COSTA, Paula Maria de Carvalho Pinto; HOMEM, Armando Luis de Carvalho; PIZARRO, José Augusto de Sotto Mayor (eds.) - Ibéria, quatrocentos/quinhentos, duas décadas de cátedra (1984-2006): homenagem a Luís Adão da Fonseca. Porto: CEPESE, 2009, pp. 47-90.

6. MUHAJ, Ardian - Portugal e a Coroa de Aragão nos séculos XIV-XV. A guerra dos Cem Anos e a sua influência na decadência da Catalunha e na expansão de Portugal. Lisboa: Universidade de Lisboa, 2006. Dissertação de Mestrado, pp. 55-56.

7. SUÁREZ FERNÁNDEZ, Luis - Castilla, el cisma y la crisis conciliar (1378-1440). Madrid: Consejo Superior de Investigaciones Científicas, Escuela de Estudios Medievales, 1960, pp. 16-19.

8. RUSSELL, Peter Edward - The English intervention in Spain and Portugal in the time of Edward III and Richard II. Oxford: Clarendon Press, 1955. 
9. FONSECA, Luis Adão de - O essencial sobre o Tratado de Windsor. Lisboa: Imprensa Nacional - Casa da Moeda, 1986.

10. SÁNCHEZ SESA, Rafael - "El Cisma de Occidente en la Península Ibérica: religión y propaganda en la guerra castellano-portuguesa". in Estudos em homenagem ao professor doutor José Marques. Vol. 4. Porto: Universidade do Porto, 2006, pp. 307-320.

11. Para el conocimiento de la situación portuguesa en el Cisma de Occidente contamos con dos monografías: BAPTISTA, Julio - "Portugal e o Cisma de Ocidente". Lusitania Sacra 1 (1956), pp. 65-203; y COSTA, António Domingues de Sousa - Monumenta Portugaliae Vaticana. Vol. 3/1: A Península Ibérica e o Cisma de Ocidente, repercussão do cisma na nacionalidade portuguesa do século XIV e XV. Roma-Braga: Livraria Editorial Franciscana, 1982.

12. Arquivo Nacional da Torre do Tombo (ANTT), Bulas, maço 26, documento 15. Editado en COSTA, António Domingues de Sousa - Monumenta Portugaliae Vaticana. Vol. 2. Roma-Braga: Livraria Editorial Franciscana, 1970, pp. CVIII-CXXII.

13. ANTT, Bulas, maço 5, documento 9, y ASV, Registra Lateraniensia, 12, fols. 10v.-12v. Editado en COSTA, António Domingues de Sousa - Monumenta Portugaliae Vaticana. Vol. 2, pp. CVIII-CXXII.

14. ANTT, Gavetas, gaveta 18, maço 11, documento 4. Editado como documento 5 en Monumenta Henricina. Vol. 2. Coimbra: Comissão Executiva das Comemorações do V Centenário da Morte do Infante D. Henrique, 1961, pp. 7-32; y como documento 4576 en As Gavetas da Torre do Tombo. Vol. 9. Lisboa: Centro de Estudos Históricos Ultramarinos, 1971, pp. 608-636.

15. Archivo General de Simancas (AGS), Patronato Regio, legajo 49, documento 15. Editado como documento 43 en SUÁREZ FERNÁNDEZ, Luis - Relaciones entre Portugal y Castilla..., pp. 177-178. SANTAREM, Visconde de - Quadro elementar das relações politicas e diplomaticas de Portugal com as diversas potencias do mundo, desde o principio da monarchia portugueza ate aos nossos dias. Vol. 3. París: J. P. Aillaud, 1843, pp. 40-41.

16. ANTT, Gavetas, gaveta 18, maço 11, documento 4. Editado como documento 37 en Monumenta Henricina. Vol. 3. Coimbra: Comissão Executiva das Comemorações do V Centenário da Morte do Infante D. Henrique, 1961, pp. 58-69; y como documento 4576 en As Gavetas da Torre do Tombo... Vol. 9, pp. 608-636.

17. AGS, Patronato Regio, legajo 49, documentos 15 y 53. ANTT, Gavetas, gaveta 17, maço 6, documento 16. ANTT, Leitura Nova, livro 61 (livro das pazes), fols. 142r.-165r. Editado como documento 9 en Monumenta Henricina. Vol. 4. Coimbra: Comissão Executiva das Comemorações do V Centenário da Morte do Infante D. Henrique, 1961, pp. 18-53; como documento 4555 en As Gavetas da Torre do Tombo... Vol. 9, pp. 500-501; y como documento 165 en SUÁREZ FERNÁNDEZ, Luis, TORRE, Antonio de la - Documentos referentes a las relaciones con Portugal durante el reinado de los Reyes Católicos. Vol. 1. Valladolid: Consejo Superiore de InvestigationesCientíficas, 1958, pp. 253-273.

18. DUARTE, Luis Miguel - Ceuta 1415, seicentos anos depois. Lisboa: Livros Horizonte, 2015.

19. La participación de Portugal en los concilios de Pisa (1409) y de Constanza (1414-1418) ha sido estudiada en MILLET, Hélène - "La participation de Portugal au Concile de Pise (1409)". in A Igreja e o clero português no contexto europeu. Lisboa: Centro de Estudos de História Religiosa da Universidade Católica Portuguesa, 2005, pp. 233-254; FILHO, Franklin Manuel Tavares - "Os Portugueses no Concílio de Constança (1416-1418): Questões e Problemas”. Plêthos. Niterói 4, 1 (2014), pp. 187-203; GROHE, Johannes - "Spanien und die großen Jonzilien von Konstanz und Basel". in HERBERS, Klaus, JASPERT, Nikolas (ed.) - "Das kommt mir spanisch vor" - Eigenes und Fremdes in den deutsch-spanischen Beziehungen des späten Mittelalters. Münster: LIT Verlag, 2004, pp. 493-509.

20. En este sentido resulta interesantes trabajos de conjunto como los de ALMEIDA, Fortunato História da Igreja em Portugal. Vol. 2. Porto: Editorial Portucalense, 1967, y VIGIL MONTES, Néstor "Eclesiásticos en la construcción política de una nueva dinastía: los clerici regis de la primera generación de la administración de Juan I de Portugal (1385-1415)”. e-Humanista 43 (2019), pp. 
89-106; así como algunos que tratan sobre cuestiones particulares como los de SANTOS, Maria Alice Pereira - A sociología da representação político-diplomática no Portugal de D. João I. Lisboa: Universidade Aberta, 2015. Tese de doutoramento; GOMES, Rita Costa - The Making of a Court Society. Kings and Nobles in Late Medieval Portugal. Cambridge: Cambridge University Press, 2003; HOMEM, Armando Luís de Carvalho - O desembargo régio: 1320-1433. Porto: Instituto Nacional de Investigação Cientifica. Centro de História da Universidade do Porto, 1985. HOMEM, Armando Luís de Carvalho - "Conselho real ou conselheiros do rei? A propósito dos privados de D. João I". Revista da Faculdade de Letras da Universidade do Porto: História (Série II) 4 (1987), pp. 9-68. Tampoco debemos olvidar las biografías de alguno de estos eclesiásticos que serán destacadas en el momento de introducirlos.

21. En este sentido resultan de enorme interés las recopilaciones de documentos de la Monumenta Henricina, de las Gavetas da Torre do Tombo y la obra de Luis Suárez Fernández sobre las relaciones entre Castilla y Portugal en época del infante don Enrique. Monumenta Henricina. Vols. 1-3. Coimbra: Comissão Executiva das Comemorações do V Centenário da Morte do Infante D. Henrique, 1960-1961. As Gavetas da Torre do Tombo. Vols. 1, 2, 7, 8 y 9. Lisboa: Centro de Estudos Históricos Ultramarinos, 1960-1971. SUÁREZ FERNÁNDEZ, Luis - Relaciones entre Portugal y Castilla ...

22. Para el conocimiento de las fuentes documentales procedentes del Archivo Secreto Vaticano es fundamental acudir a la Monumenta Portugaliae Vaticana de António Domingues da Sousa Costa. COSTA, António Domingues de Sousa - Monumenta Portugaliae Vaticana ...., Vol. 2. COSTA, António Domingues de Sousa - Monumenta Portugaliae Vaticana ...., Vol. 3/1.

23. La documentación boloñesa fue objeto de edición por parte de algunos investigadores italianos de comienzos del siglo XX como Ludovico Prati o Albano Sorbelli. Asimismo, para el caso portugués algunos de estos datos fueron ampliados por Artur Moreira de Sá en la obra Chartularium Universitatis Portugalensis. PRATI, Ludovico - Chartularium Studii Bononiensis. Vol. 4. Bologna: Commisione per la Storia dell'Università di Bologna, 1919. SORBELLI, Albano (ed.) - Liber secretus iuris cesarei dell'Universitá di Bologna. Vol. 1: 1378-1420. Bolonia: Università di Bologna, 1938. SÁ, Artur Moreira de (ed.) - Chartularium Universitatis Portugalensis (1288-1537). Vol. 2: 1377-1408. Lisboa: Instituto de Alta Cultura, 1968.

24. BECEIRO PITA, Isabel - "La consolidación del personal diplomático entre Castilla y Portugal, 1392-1455". in GONZÁLEZ JIMÉNEZ, Manuel (ed.) - La Península Ibérica en la era de los descubrimientos 1391-1492, Actas de las III Jornadas Hispano-Portuguesas de Historia Medieval. Vol. 2. Sevilla: Consejería de Cultura de la Junta de Andalucía, 1997, p. 1735.

25. VENTURA, Margarida Garcez - Igreja e poder no século XV. Dinastia de Avis e liberdades eclesiásticas (1383-1450). Lisboa: Edições Colibri, 1997, pp. 95-99. MARQUES, José - "Relações entre a Igreja e o Estado em Portugal, no século XV". Revista da Faculdade de Letras da Universidade do Porto: História (Série II) 11 (1994), pp. 141-145.

26. BRÁSIO, António - “Erecção da Metrópole Lisbonense”. Lusitania Sacra 2 (1957), pp. 51-56.

27. MARQUES, António Henrique de Oliveira - Nova História de Portugal. Direcção de Joel Serrão e António Henrique de Oliveira Marques. Vol. 4: Portugal na crise dos séculos XIV e XV. Lisboa: Editorial Presença, 2000, p. 379. OLIVEIRA SERRANO, César - Beatriz de Portugal, la pugna dinástica Avis-Trastámara. Santiago de Compostela: Instituto de Estudios Gallegos Padre Sarmiento, 2005, p. 82 y 96.

28. Este proceso de purga fue analizado en DÍAZ MARCILLA, Francisco José - "El papel del clero en el cambio dinástico en Portugal (1378-1388)". Reti Medievali 19/2 (2018), pp. 131-170.

29. HOMEM, Armando Luís de Carvalho - "Conselho real ou conselheiros do rei? A propósito dos privados de D. João I" ..., pp. 9-68.

30. HOMEM, Armando Luís de Carvalho - O desembargo régio: 1320-1433 ...

31. SOUSA, Armindo de - As cortes medievais portuguesas: 1385-1490. Vol. 1. Lisboa: Instituto Nacional de Investigação Científica, 1990. 
32. VENTURA, Margarida Garcez - Igreja e poder no século XV..., pp. 95-99. MARQUES, José "Relações entre a Igreja e o Estado em Portugal, no século XV"..., pp. 141-145. MARQUES, José "Legislação e práctica judicial como fontes de tensões entre D. João I e a Igreja". Revista de História 10 (1990), pp. 9-34.

33. Una biografía sobre este eclesiástico se puede encontrar en VIGIL MONTES, Néstor - "Pedro de Noronha (1423-1452)". in FONTES, João Luís Inglês (ed.) - Bispos e arcebispos de Lisboa. Lisboa: Livros Horizonte, 2018, pp. 495-501.

34. HOMEM, Armando Luís de Carvalho - "Conselho real ou conselheiros do rei? A propósito dos privados de D. João I" ..., pp. 56-60.

35. ASV, Obligationes, registro 48A, fol. 110r. Citado en EUBEL, Konrad - Hierarchia Catholica Medii Aevi. Vol.1. Ratisbona: Monasterii Sumptibus et typis librariae Regensbergianae, 1913, p. 196.

36. ASV, Obligationes, registro 48A, fol. 101r. Citado en EUBEL, Konrad - Hierarchia Catholica Medii Aevi ..., p. 144.

37. Los hitos de la carrera eclesiástica de João Afonso Esteves de Azambuja, enormemente ligados a su trayectoría diplomática, serán analizados detalladamente en el transcurso del artículo. Una biografía de enorme interés sobre su figura la escribió COSTA, Antonio Domingues de Sousa - "D. João Afonso de Azambuja, cortesão, bispo, arcebispo, cardeal e fundador do convento das dominicanas do Salvador de Lisboa". Arquivo Histórico Dominicano Português 4/2 (1989), pp. 1-150. También resultan interesantes los trabajo de GRAF, Carlos Eduardo de Verdier - D. João Esteves da Azambuja: exemplo da interligação de poderes (séculos XIV e XV). Porto: Universidade do Porto, 2011. Dissertação de Mestrado; y de FONTES, João Luís Inglês - "João Afonso Esteves de Azambuja (1402-1415)". in FONTES, João Luís Inglês (ed.) - Bispos e arcebispos de Lisboa. Lisboa: Livros Horizonte, 2018, pp. 471-484.

38. VILAR, Hermínia Vasconcelos - As dimensiões de um poder, a diocese de Évora na Idade Média. Lisboa: Editorial Estampa, 1999, p. 97. VILAR, Hermínia Vasconcelos - "Na sombra da crise de 1383-85: o governo do bispo D. João de Évora”. Eborensia 39-40 (2008), pp. 103-116.

39. CUNHA, Rodrigo da - Historia ecclesiastica dos arcebispos de Braga. Vol. 2. Braga: Imprenta Manoel Cardozo, 1635, p. 216.

40. HOMEM, Armando Luís de Carvalho - O desembargo régio: 1320-1433 ..., p. 272.

41. LOPES, Fernão - Chronica de el-rei D. João I editada por Luciano Cordeiro. Vol. 3. Lisboa: Escriptorio, 1898, pp. 98-103 (parte I, cap. CLIX).

42. GOMES, Rita Costa - The Making of a Court Society ..., p. 64.

43. ANTT, Chancelaria de D. João I, liv. 1, 29r.

44. ANTT, Chancelaria de D. João I, liv. 1, 113r.

45. CUNHA, Rodrigo da - Catálogo dos bispos do Porto (Segunda impressam addicionado e com supplementos de varias memorias ecclesiasticas). Vol. 2. Porto: Oficina prototypa episcopal, 1742.

46. SYLVA, Joseph Soares de - Memorias para a História de Portugal que comprehendem o governo delrey D. João I. Vol. 2. Lisboa: Officina de Joseph Antonio da Sylva, 1730, p. 581.

47. LOPES, Fernão - Chronica de el-rei D. Fernando. Ed. Luciano Cordeiro. Vol. 2. Lisboa: Escriptorio, 1895, pp. 17-20 (cap. LXV). Citado en GOMES, Rita Costa - The Making of a Court Society. Kings and Nobles in Late Medieval Portugal. Cambridge: Cambridge University Press, 2003, p. 115.

48. LOPES, Fernão - Chronica de el-rei D. Fernando. Ed. Luciano Cordeiro. Vol. 3. Lisboa: Escriptorio, 1896, pp. 28-30 (cap. CXXIV).

49. COSTA, Antonio Domingues de Sousa - "D. João Afonso de Azambuja" ..., p. 15.

50. ANTT, Chancelaria de D. João I, liv. 2, 87r.

51. FARELO, Mário - A oligarquía camarária de Lisboa (1325-1433). Lisboa: Universidade de Lisboa, 2009. Tese de doutoramento, p. 735.

52. LEITÃO, André de Oliveira - "Leges et canones. Portuguese law students in 14th and 15th century Italy. Methodological horizons and problems”. in VILAR, Hermínia; BRANCO, Maria João 
(Eds.) - Ecclesiastics and political state building in the Iberian monarchies, 13th-15th centuries, Évora: Publicações do CIDEHUS, 2016, pp. 275-290.

53. ASB, Liber Secretus Iuris Caesarei, liber 1, 6v. Editado en SORBELLI, Albano (ed.) - Liber secretus iuris cesarei dell'Universitá di Bologna. Vol. 1: 1378-1420. Bolonia: Università di Bologna, 1938, pp. 19-20; y en SÁ, Artur Moreira de (ed.) - Chartularium Universitatis Portugalensis (1288-1537). Vol. 2: 1377-1408. Lisboa: Instituto de Alta Cultura, 1968, p. 206. SILVA, Nuno Espinosa Gomes da - "João das Regras e outros juristas portugueses da Universidade de Bolonha (1378-1421)". Revista da Faculdade de Direito da Universidade de Lisboa 12 (1960), pp. 16-17.

54. COSTA, António Domingues de Sousa - Portugueses no Colégio de S. Clemente e Universidade de Bolonha durante o século XV. Vol. 1. Bolonia: Publicaciones del Real Colegio de España, 1990, p. 269.

55. PIANA, Celestino - Nuovi documenti sull'Università di Bologna e sul Collegio di Spagna. Vol. 1. Bolonia: Publicaciones del Real Colegio de España, 1976, p. 313.

56. MAZZETTI, Serafino - Repertorio di tutti i professori antichi e moderni della famosa Università e del célebre istituto delle scienze di Bologna. Bolonia: Arnaldo Forni Editore, 1988, p. 203.

57. Arquivo da Casa da Moeda de Lisboa (ACML), Livro dos moedeiros, 2v. Editado como documento 4 en PERES, Damião - História dos moedeiros de Lisboa como classe privilegiada. Vol. 1. Lisboa: Academia Portuguesa da História, 1964, p. 105

58. FONTES, João Luís Inglês - “João Afonso Esteves de Azambuja (1402-1415)” ..., p. 472.

59. VILAR, Hermínia Vasconcelos - "Na sombra da crise de 1383-85: o governo do bispo D. João de Évora" ..., pp. 108.

60. HOMEM, Armando Luís de Carvalho - O desembargo régio: 1320-1433 ..., p. 349.

61. HOMEM, Armando Luís de Carvalho - O desembargo régio: 1320-1433 ..., pp. 330-331.

62. GUENÉE, Bernard - Occidente durante los siglos XIV y XV, los estados. Barcelona: Labor, 1973, p. 215.

63. ANTT, Gavetas, gaveta 14, maço 1, documento 20, fols. 3v.-10r. Editado en MARQUES, José - "O senhorio de Braga no século XV: principais documentos para o seu estudo". Bracara Augusta 46 (1997), pp. 39-51.

64. RIBEIRO, Luís Mário Araújo - A transição do senhorio episcopal portucalense para a Coroa em 1406. Porto: Universidade do Porto, 2009. Dissertação de mestrado.

65. Podemos encontrar algunos datos sobre la biografía de este eclesiástico en ALMEIDA, Fortunato - História da Igreja em Portugal. Vol. 2. Porto: Editorial Portucalense, 1967, p. 380.

66. Archivo General de la Corona de Aragón (ACA), Chancillería, registro 1256, fol. 188r. Editado en ARNAUT, Salvador Dias - A crise nacional dos fins do século XIV. Vol. 1: A sucessão de D. Fernando. Coimbra: Universidade de Coimbra, 1960, pp. 143-144.

67. Para conocer con más detenimiento las relaciones entre los cambios de fidelidad entre los papas del Cisma de Occidente protagonizados por D. Fernando I de Portugal y sus vaivenes en política exterior. OLIVEIRA SERRANO, César - Beatriz de Portugal, la pugna dinástica AvisTrastámara. Santiago de Compostela: Instituto de Estudios Gallegos Padre Sarmiento, 2005, pp. $72-82$.

68. Biblioteca Apostolica Vaticana (BAV), Barberiniani latini, códice 872, fol. 99r-104r. Publicado en COSTA, António Domingues de Sousa - Monumenta Portugaliae Vaticana ..., Vol. 3/1, pp. 387-392.

69. LOPES, Fernão - Chronica de el-rei D. João I... Vol. 3, p. 172 (parte I, cap. CLXXXII). COELHO, André Madruga - "Ecclesiastical Support to the Master of Avis: An Analysis from the Aclamation Act of 1385". En la España Medieval 40 (2017), p. 153.

70. LOPES, Fernão - Chronica de el-rei D. João I. Vol. 3, p. 172 (parte I, cap. CLXXXII).

71. Archivio di Stato di Bologna (ASB), Rogiti di Paolo Cospi, busta protoc. 16, fol. 37v. Editado como documento 219 en PRATI, Ludovico - Chartularium Studii Bononiensis..., pp. 139-140, y en COSTA, António Domingues de Sousa - Monumenta Portugaliae Vaticana ..., Vol. 3/1, pp. 616-617.

72. Así lo sugiere COSTA, António Domingues de Sousa - Monumenta Portugaliae Vaticana ..., Vol. 3/1, pp. 387-392. 
73. Se conserva la entrada correspondiente en el libro de aniversarias de la catedral de Coimbra, ANTT, Cabido da Sé de Coimbra, livro 5 (livro das calendas 2), 81v., editado en DAVID, Pierre, y SOARES, Torquato da Sousa - Liber anniversariorum ecclesiae cathedralis colimbriensis: livro das kalendas. Vol. 2. Coimbra: Universidade de Coimbra, 1947, p. 45.

74. ANTT, Sé de Coimbra, $2^{\circ}$ Incorporação, maço 94, documento 4498. Editado en GOMES, Saul António - "Três bibliotecas particulares na Coimbra de Trezentos, em torno das elites e das culturas urbanas medievais". Revista de História das Ideias 24 (2003), pp. 45-49, y en COSTA, Avelino de Jesus da - "A biblioteca e o tesouro da Sé de Coimbra nos séculos XI a XVI". Boletim da Biblioteca da Universidade de Coimbra 38 (1983), pp. 201-203.

75. Cristina Cunha y Judite Freitas lo consideraron conselheiro ad-hoc de D. Fernando, en CUNHA, Maria Cristina; FREITAS, Judite - "Homens de estado, crises políticas e guerra: Portugal, séculos XIV-XV”. in COELHO, Maria Helena da Cruz; GOMES, Saul António; REBELO, António Manuel Ribeiro (coords.) - A guerra e a sociedade na Idade Média. VI Jornadas Luso-Espanholas de Estudos Medievais. Vol. 2. Coimbra: Sociedade Portuguesa de Estudos Medievais 2009, p. 139.

76. Arquivo Histórico da Câmara do Porto (AHMP), Livro B, fols. 302-308v. SOUSA, Armindo de - As cortes medievais portuguesas: 1385-1490. Vol. 2. Lisboa: Instituto Nacional de Investigação Científica, 1990.

77. LOPES, Fernão - Chronica de el-rei D. João I. Ed Luciano Cordeiro. Vol. 2. Lisboa: Escriptorio, 1897, pp. 185-188 (parte I, cap. CXII), y ANTT, Gavetas, gaveta 17, maço 6, documento 11, editado como documento 4190 en As Gavetas da Torre do Tombo. Vol. 7. Lisboa: Centro de Estudos Históricos Ultramarinos, 1968, pp. 252-255. SANTAREM, Visconde de - Quadro elementar das relações politicas e diplomaticas de Portugal com as diversas potencias do mundo, desde o principio da monarchia portugueza ate aos nossos dias. Vol. 1. París: J. P. Aillaud, 1842, p. 247.

78. ANTT, Gavetas, gaveta XVII, maço 6, documento 10, editado como documento 4189 en As Gavetas da Torre do Tombo. Vol. 7. Lisboa: Centro de Estudos Históricos Ultramarinos, 1968, pp. 198-241. SANTAREM, Visconde de - Quadro elementar ..., Vol. 1, p. 242.

79. Así lo señaló Salvador Días Arnaut pero no podemos confirmarlo ya que este autor no refrenda este dato con una fuente primaria que tampoco hemos encontrado. ARNAUT, Salvador Dias - A crise nacional dos fins do século XIV ..., p. 43.

80. CUNHA, Maria Cristina; FREITAS, Judite - "Homens de estado, crises políticas e guerra: Portugal, séculos XIV-XV"..., p. 139.

81. LOPES, Fernão - Chronica de el-rei D. João I, ed. cit. Vol. 4. Lisboa: Escriptorio, 1897, p. 12 (parte II, cap. I).

82. HOMEM, Armando Luís de Carvalho - O desembargo régio: 1320-1433 ..., pp. 382-383.

83. HOMEM, Armando Luís de Carvalho - "Conselho real ou conselheiros do rei? A propósito dos privados de D. João I" ..., pp. 9-68.

84. CONTAMINE, Philippe - "Le moyen âge occidental a-t-il connu des serviteurs de l'État?". in Les serviteurs de l'état au moyen âge. Actes du 29 e congrês de la Societé des historiens médiévistes de l'enseigneiment supérieur public. Pau: Publications de la Sorbonne, 1998, pp. 9-20.

85. OLAVO, Carlos - João das Regras, jurisconsulto e homem de estado, Guimarães: Lisboa: Livraria Editora Guimarães e C’a , 1941. SILVA, Nuno Espinosa Gomes da - "João das Regras e outros juristas portugueses da Universidade de Bolonha (1378-1421)". Revista da Faculdade de Direito da Universidade de Lisboa 12 (1960), pp. 5-35. HOMEM, Armando Luís de Carvalho - "O doutor João das Regras no desembargo e no conselho régios (1384-1404). Breves notas". in Estudos de história de Portugal, Homenagem a A. H. de Oliveira Marques. Vol. 1: séculos X-XV. Lisboa: Estampa, 1982, pp. 241-253.

86. HOMEM, Armando Luís de Carvalho - "Diplomacia e diplomatas nos finais da Idade Média: a propósito de Lourenço Anes Fogaça, chanceler-mor (1374-99) e negociador do Tratado de Windsor". in Colóquio comemorativo do VI Centenário do Tratado de Windsor. Porto: Universidade do Porto, 1986, pp. 221-240. FARELO, Mario - "La représentation de la couronne portugaise à 
Avignon et ses agents (1305-1377)". Anuario de Estudios Medievales 40/2 (2010), pp. 723-763. FARIA, Tiago Viúla de - "Por proll e serviço do reino? O desempenho dos negociantes portugueses do Tratado de Windsor e suas consequências nas relações com Inglaterra". in COELHO, Maria Helena da Cruz; GOMES, Saul António; REBELO, António Manuel Ribeiro (coords.) - A guerra e a sociedade na Idade Média. VI Jornadas Luso-Espanholas de Estudos Medievais. Vol. 2. Coimbra: Sociedade Portuguesa de Estudos Medievais, 2009, pp. 209-227.

87. VIGIL MONTES, Néstor - "Cuestiones metodológicas acerca del rol de los eclesiásticos en la formación de la diplomacia de las monarquías europeas en la Baja Edad Media". Vegueta, Anuario de la Facultad de Geografía e Historia de la Universidad de las Palmas de Gran Canaria 18 (2018), pp. 403-423.

88. NIETO SORIA, José Manuel - Iglesia y génesis del estado moderno en Castilla (1369-1480). Madrid: Editorial Complutense, 2009, p. 291. Para observar el caso portugués DÍAZ MARCILLA, Francisco José - "El clero en el contexto diplomático de la Guerra de los Cien Años: una mirada desde las crónicas oficiales al período ibérico (1366-1388)". in VIGIL MONTES, Néstor (dir.) - Comunicación política y diplomacia en la Baja Edad Media. Évora: Publicações do CIDEHUS, 2019, pp. 47-74.

89. VILLARROEL GONZÁLEZ, Óscar - "Eclesiásticos en la diplomacia castellana en el siglo XV". Anuario de Estudios Medievales 40/2 (2010), pp. 810-812.

90. PÉQUIGNOT, Stephane - Au nom du roi: practique diplomatique et pouvoir durant le règne de Jacques II d'Aragon, 1291-1327. Madrid: Casa de Velázquez, 2009, p. 193.

91. NIETO SORIA, José Manuel - Iglesia y génesis del estado moderno en Castilla ..., p. 292.

92. BECEIRO PITA, Isabel - "La consolidación del personal diplomático entre Castilla y Portugal, 1392-1455”. in GONZÁLEZ JIMÉNEZ, Manuel (ed.) - La Península Ibérica en la era de los descubrimientos 1391-1492, Actas de las III Jornadas Hispano-Portuguesas de Historia Medieval. Vol. 2. Sevilla: Consejería de Cultura de la Junta de Andalucía, 1997, p. 1736

93. VILLARROEL GONZÁLEZ, Óscar - "Eclesiásticos en la diplomacia castellana”..., pp. 816-817.

94. LOPES, Fernão - Chronica de el-rei D. João I, ed. cit., vol. 6. Lisboa: Escriptorio, 1898, pp. 9-12 (parte II, cap. CLXXIII). Citado en COELHO, Maria Helena da Cruz - D. João I: o que re-colheu Boa Memória. Mem Martins: Círculo de Leitores, 2005, pp. 66-68.

95. No contamos con un testimonio escrito sobre el desarrollo de la embajada, pero podemos datarla a través de un documento de 25 de junio de ese año en el que se da testimonio de unos dineros que mercaderes genoves habían prestado a los delegados de la embajada y otro documento de 1 de julio en el que se recompensan los servicios prestados en la embajada al canónigo de Lisboa, ANTT, Chancelaria de D. João I, livro 5, 9r. y 5v. Publicados en COSTA, António Domingues de Sousa - Monumenta Portugaliae Vaticana..., Vol. 3/1, pp. 587-588.

96. ANTT, Gavetas, gaveta 18, maço 3, documento 25. Editado As Gavetas da Torre do Tombo. Vol. 8. Lisboa: Centro de Estudos Históricos Ultramarinos, 1970, pp. 312-320.

97. ANTT, Gavetas, gaveta 17, maço 6, documento 7; y ANTT, Gavetas, gaveta 18, maço 3, documento 26. Publicadas en As Gavetas da Torre do Tombo. Vol. 7. Lisboa: Centro de Estudos Históricos Ultramarinos, 1968, pp. 161-163, y en As Gavetas da Torre do Tombo ..., Vol. 8, pp. 321-323.

98. ASV, Obligationes et Solutiones, registro 51, fols. 20v. y 66r. Publicado en COSTA, António Domingues de Sousa - Monumenta Portugaliae Vaticana ..., Vol. 3/1, pp. 515-516.

99. LOPES, Fernão - Chronica de el-rei D. João I ..., Vol. 6, pp. 13-14 (parte II, cap. CLXXIV).

100. ANTT, Bulas, maço 5, documento 9; ASV, Registra Lateranensia, registro 12, fols. 10v.-12v.; y ANTT, Leitura Nova, livro 38 (Livro I dos Reis), fols. 8r.-9v. Publicado en COSTA, António Domingues de Sousa - Monumenta Portugaliae Vaticana..., Vol. 2, p. CVIII-CXXII. Traducida al portugués en la crónica de LOPES, Fernão - Chronica de el-rei D. João I ..., Vol. 6, pp. 17-21 (parte II, cap. CLXXV). Citada en SANTAREM, Visconde de - Quadro elementar das relações politicas $e$ 
diplomaticas de Portugal com as diversas potencias do mundo, desde o principio da monarchia portugueza ate aos nossos dias. Vol. 8. Paris: J. P. Aillaud, 1853, pp. 393-394.

101. ANTT, Bulas, maço 26, documento 15; ASV, Registra Lateranensia, registro 12, fols. 40r.-41r.; y ANTT, Leitura Nova, livro 38 (Livro I dos Reis), fols. 8r.-9v. Publicado en COSTA, António Domingues de Sousa - Monumenta Portugaliae Vaticana ..., Vol. 2, p. CVIII-CXXII. Traducida al portugués en la crónica de LOPES, Fernão - Chronica de el-rei D. João I ..., Vol. 6, pp. 21-28 (parte II, cap. CLXXVI). Citada en SANTAREM, Visconde de - Quadro elementa ..., Vol. 8, pp. 395-396.

102. ASV, Registra Lateranensia, registro 17, fol. 47r. Publicado en COSTA, António Domingues de Sousa - Monumenta Portugaliae Vaticana..., Vol. 3/1, p. 589.

103. ASV, Registra Lateranensia, registro 12, fols. 64v.-65r., 159v. Publicado en COSTA, António Domingues de Sousa - Monumenta Portugaliae Vaticana..., Vol. 3/1, pp. 590-591.

104. SÁNCHEZ HERRERO, José - "Los obispos castellanos y su participación en el gobierno de Castilla, 1350-1406". in RUCQUOI, Adeline (coord.) - Realidad e imágenes de poder. España a fines de la Edad Media. Valladolid: Ámbito Ediciones, 1988, pp. 106-107.

105. CUNHA, Rodrigo da - Historia ecclesiastica dos arcebispos de Braga ..., p. 214.

106. CUNHA, Rodrigo da - Historia ecclesiastica dos arcebispos de Braga ..., pp. 212-215.

107. ASV, Obligationes, registro 57, fol. 35. Citado en EUBEL, Konrad - Hierarchia Catholica Medii Aevi..., p. 196.

108. SILVA, Manuel Telles de - Collecçam dos documentos e memorias da Academia Real da Historia Portuguesa. Lisboa: Oficina de Pascual de Silva, 1724, pp. 138-139.

109. ASV, Registra Lateranensia, registro 29, fols. 188r.-188v. Publicado en BRÁSIO, António - "Erecção da Metrópole Lisbonense". Lusitania Sacra. Lisboa 2 (1957), pp. 51-56.

110. ASV, Obligationes et Solutiones, registro 48, 152v. Publicado en COSTA, António Domingues de Sousa - Monumenta Portugaliae Vaticana ..., Vol. 3/1, p. 592.

111. Expresión repetida en las dos concesiones, la del padroado en ANTT, Chancelaria de D. João I, livro 2, 45r.-45v. Publicado en COSTA, António Domingues de Sousa - Monumenta Portugaliae Vaticana ..., Vol. 3/1, pp. 776-777; y la de la jurisdicción en ANTT, Chancelaria de D. João I, livro 2, 91v.-92r. Publicado en COSTA, António Domingues de Sousa - Monumenta Portugaliae Vaticana..., Vol. 3/1, pp. 777-778.

112. RUSSELL, Peter Edward - The English intervention in Spain and Portugal..., pp. 398-399. SANTAREM, Visconde de - Quadro elementar das relações politicas e diplomaticas de Portugal com as diversas potencias do mundo, desde o principio da monarchia portugueza ate aos nossos dias. Vol. 14. París: J. P. Aillaud, 1865, pp. 82-94.

113. AGS, Patronato Real, legajo 47, documento 27. SANTAREM, Visconde de - Quadro elementar.... Vol. 1, pp. 275.

114. ANTT, Manuscritos, número 364, fol. 457r. British Museum of London (BML), Biblioteca Cotton, Nero, B. I., fol. 41r. Editado en PIMENTA, Alfredo - “As treguas de Monção de 1389”. in Idade-Média (Problemas \& soluçõens). Lisboa: Edições Ultramar, 1946, pp. 320-328.

115. SANTAREM, Visconde de - Quadro elementar..., Vol. 1, pp. 276-277.

116. AGS, Patronato Real, legajo 47, documentos 29,4, 30, 31 y 32, y legajo 49, documento 1.

117. AGS, Patronato Real, legajo 47, documento 33, editado como documento 5 en SUÁREZ FERNÁNDEZ, Luis - Relaciones entre Portugal y Castilla ..., pp. 93-96.

118. LÓPEZ DE AYALA, Pedro - Crónica de Enrique III. in Crónicas de los reyes de Castilla. Ed. Eugenio Llaguno Amirola. Vol. 1: Crónicas de Pedro I, Enrique II, Juan I y Enrique III. Madrid: Imprenta de Don Antonio de Sancha, 1779, pp. 509-510 (Crónica de Enrique III, año IV, cap. V).

119. AGS, Patronato Real, legajo 49, documento 10 editado como documento 7 en SUÁREZ FERNÁNDEZ, Luis - Relaciones entre Portugal y Castilla ..., pp. 96-98.

120. SANTAREM, Visconde de - Quadro elementar ..., Vol. 1, p. 278. 
121. MONTOJO JIMÉNEZ, Carlos - La diplomacia castellana bajo Enrique III, estudio especial de la embajada de Ruy González de Clavijo a la corte de Tamerlán. Madrid: Escuela Diplomática, 2004 (1944), p. 67. MITRE FERNÁNDEZ, Emilio - "Notas sobre la ruptura castellano-portuguesa de 1396". Revista Portuguesa de História 12 (1969), pp. 213-221.

122. SANTAREM, Visconde de - Quadro elementar ..., Vol. 1, pp. 281-282.

123. BECEIRO PITA, Isabel - "Las negociaciones entre Castilla y Portugal en 1399". Revista da Faculdade de Letras da Universidade do Porto: História (Série II) 13 (1996), p. 168.

124. ANTT, Gavetas, gaveta 17 , maço 8 , documento 32, editada con datación errónea en 28 de febrero de 1392, que debemos de corregir a 1399 por encontrarse todos los protagonistas y la coyuntura de las negociaciones de esa fecha, editado como documento 2391 en As Gavetas da Torre do Tombo. Vol. 2. Lisboa: Centro de Estudos Históricos Ultramarinos, 1962, pp. 762-764.

125. Paradojicamente en la breve descripción de la actuación de Nuno Álvares de Pereira en su propia crónica del Condestable, se omite la participación de Rui Lourenço y Álvaro Peres. LOPES, Fernão - Chronica do Condestabre de Portugal Dom Nuno Alvarez Pereira. Ed. Joaquim Mendes dos Remédios. Lisboa: F. Franca Amado, 1911, pp. 188-191 (cap. LXXII).

126. En palabras de Fernão Lopes, el poder otorgado por D. João I para las negociaciones a sus cuatro delegados: Nuno Álvares Pereira, João Afonso Esteves de Azambuja, Rui Lourenço y Álvaro Peres, exigía la unanimidad para las decisiones tomadas: "E posto que os quoatro acordasem e huu delles nã, que seu acordo fose nada"; LOPES, Fernão - Chronica de el-rei D. João I, ed. cit., vol. 7. Lisboa: Escriptorio, 1898, p. 44 (parte II, cap. CLXXIX).

127. SANTAREM, Visconde de - Quadro elementar ..., Vol. 1, p. 282.

128. AGS, Patronato Real, legajo 47, documento 34, editado como documento 18 en SUÁREZ FERNÁNDEZ, Luis - Relaciones entre Portugal y Castilla ..., pp. 116-117.

129. EUBEL, Konrad - Hierarchia Catholica Medii Aevi ..., p. 196.

130. VEAS ARTESEROS, Francisco de Asís - Itinerario de Enrique III. Murcia: Universidad de Murcia, 2003, p. 111.

131. ANTT, Cabido da Sé de Coimbra, livro 5 (livro das calendas 2), fol 81v., editado en DAVID, Pierre, y SOARES, Torquato da Sousa - Liber anniversariorum ecclesiae cathedralis colimbriensis ..., $\mathrm{p}$. 45.

132. SANTAREM, Visconde de - Quadro elementar ..., Vol. 1, pp. 283-285.

133. Arquivo Histórico da Câmara do Porto (AHCP), Vereações, livro 2, fol 47v., editada como documento 119 en Monumenta Henricina. Vol. 1. Coimbra: Comissão Executiva das Comemorações do V Centenário da Morte do Infante D. Henrique, 1960, p. 277.

134. AGS, Patronato Real, legajo. 49, documento 7, editado como documento 31 en SUÁREZ FERNÁNDEZ, Luis - Relaciones entre Portugal y Castilla ..., pp. 135-136.

135. AGS, Patronato Real, legajo 49, documentos 3 y 9, editados como documentos 32 y 34 en SUÁREZ FERNÁNDEZ, Luis - Relaciones entre Portugal y Castilla ..., pp. 136-158 y 162-164.

136. AGS, Patronato Real, legajo 49, documento 4, editado como documento 33 en SUÁREZ FERNÁNDEZ, Luis - Relaciones entre Portugal y Castilla ..., pp. 159-162.

137. AGS, Patronato Real, legajo 49, documento 9, editado como documento 34 en SUÁREZ FERNÁNDEZ, Luis - Relaciones entre Portugal y Castilla ..., pp. 162-164.

138. LOPES, Fernão - Chronica de el-rei D. João I ..., Vol. 7, p. 70 (parte II, cap. CLXXXVIII).

139. AGS, Patronato Real, legajo 49, documento 7 , editado como documento 31 en SUÁREZ FERNÁNDEZ, Luis - Relaciones entre Portugal y Castilla ..., pp. 135-136.

140. AGS, Patronato Real, legajo 49, documento 4, como documento 33 en SUÁREZ FERNÁNDEZ, Luis - Relaciones entre Portugal y Castilla ..., pp. 159-162.

141. AGS, Patronato Real, legajo 49, documento 9, editado como documento 34 en SUÁREZ FERNÁNDEZ, Luis - Relaciones entre Portugal y Castilla..., pp. 162-164. Esto supone que debemos de refutar la datación del 29 de mayo de 1402 dada por EUBEL, Konrad - Hierarchia Catholica Medii Aevi ..., Vol.1, p. 507. 
142. AGS, Estado, Castilla, legajo 1-1ํㅡㄴ fol. 86. Documento en cuya edición se data sin argumentos suficientes en diciembre de 1405, editado como documento 372 en SUÁREZ FERNÁNDEZ, Luis - Relaciones entre Portugal y Castilla ..., p. 186.

143. AGS, Patronato Real, legajo 49, documento 8, editado como documento 42 en SUÁREZ FERNÁNDEZ, Luis, SUÁREZ FERNÁNDEZ, Luis - Relaciones entre Portugal y Castilla ..., pp. 170-171.

144. AGS, Patronato Real, legajo 49, documento 14, editado como documento 43 en SUÁREZ FERNÁNDEZ, Luis - Relaciones entre Portugal y Castilla ..., pp. 172-175.

145. GONZÁLEZ SÁNCHEZ, Santiago - Las relaciones exteriores de Castilla a comienzos del siglo XV. La minoría de Juan II (1407-1420). Madrid: Comité Español de Ciencias Históricas, 2013, pp. 134-142. ÁLVAREZ PALENZUELA, Vicente - "Relations between Portugal and Castile in the Late Middle Ages - 13th-16th centuries". E-Journal of Portuguese History 1/1 (2003), p. 13.

146. Todo este proceso de las frustradas negociaciones de renovación de las treguas de 1402 sucedidas entre 1407 y 1411 aparece descrito en SANTAREM, Visconde de - Quadro elementar ..., Vol. 1., pp. 285-288.

147. Pedro de Noronha representó a D. Duarte en la celebración por poderes de su matrimonio con Leonor de Aragón. ANTT, Gavetas, gaveta 17, maço 4, documento 8, y Archivo General de la Corona de Aragón (ACA), Cancillería Real, Registro 2692, fols. 13v.-19v. editado como documento 91 en Monumenta Henricina ... Vol. 3, pp. 180-197. Posteriormente acompañó a la princesa en su viaje hacia Portugal a través de Castilla como se relata en la crónica de CARRILLO DE HUETE, Pedro - Crónica de Pedro Carrillo de Huete, halconero de Juan II de Castilla. Ed. Juan de Mata Carriazo. Madrid: Espasa-Calpe, 1946, pp. 18-19 (cap. 1). SANTAREM, Visconde de - Quadro elementar .... Vol. 1, p. 291.

148. BABO, Duarte - Os embaixadores portugueses nos reinos ibéricos (1431-1474): um estudo sociodemográfico. Porto: Faculdade de Letras da Universidade do Porto, 2017. Tese de Doutoramento.

149. VIGIL MONTES, Néstor - "Un eclesiástico para un reinado: el servicio del obispo conimbricense João Galvão a D. Afonso V de Portugal”. Lusitania Sacra 35 (2017), pp. 185-206.

150. MENDONÇA, Manuela - D. Jorge da Costa, cardeal de Alpedrinha. Lisboa: Edições Colibri, 1991.

151. MILLET, Hélène - "La participation de Portugal au Concile de Pise (1409)" ..., pp. 233-254.

152. ASV, Registra Supplicationum, registro 145, fol. 145r. Editado como documento 147 en Monumenta Henricina ..., Vol. 1, p. 336. Citada en SANTAREM, Visconde de - Quadro elementar ..., Vol. 8, p. 402.

153. ZURARA, Gomes Eanes de - Crónica da Tomada de Ceuta. Ed. Francisco Maria Esteves Pereira. Lisboa: Academia das Sciencias de Lisboa, 1915, p. 56 (cap. 52).

154. BAEZA HERRATZI, Alberto - Bulas de cruzada en la reconquista de Ceuta. Ceuta: Caja de ahorros y monte de piedad de Ceuta, 1987, p. 12.

155. EUBEL, Konrad - Hierarchia Catholica Medii Aevi ..., p. 507.

156. VILAR, Hermínia Vasconcelos - "Bispos na conquista de Ceuta ou os possiveis significados de uma ausência". in COELHO, Maria Helena da Cruz; HOMEM, Armando Carvalho (coord.) - As décadas de Ceuta (1385-1460). Lisboa: Caleidoscópio e Universidade Autónoma de Lisboa Luís de Camões, 2018, pp. 93-108.

157. PEREIRA, Reina Marisol Troca - Discursos dos embaixadores portugueseses no Concilio de Constança: 1415. Coimbra: Universidade de Coimbra, 1999. Disertação de mestrado, pp. 42-45.

158. En este caso seguimos la teoría apuntada por HOMEM, Armando Luís de Carvalho - O desembargo régio: 1320-1433..., pp. 330-331.

159. ACA, D. Fernando I, caja 12, documento 2120. Editado como documento 114 en Monumenta Henricina..., Vol. 2, pp. 237-239. 
160. Así aparece en la suplica enviada por D. João I de Portugal al papa Martin V el 4 de abril de 1418 ASV, Registra Supplicationum, registro 110, fol. 178r. Editado como documento 141 en Monumenta Henricina..., Vol. 2, pp. 277-281.

161. ASV, Registra Vaticana, registro 352, fol. 153v. Editado como documento 143 en Monumenta Henricina ... Vol. 2, pp. 282-286. Citada en SANTAREM, Visconde de - Quadro elementar ... Vol. 8, pp. 393-394.

162. ASV, Registra Lateraniense, registro 195, 289r. ANTT, Bulas, maço 11, documento 13. Editado como documento 144 en Monumenta Henricina. Vol. 2. Coimbra: Comissão Executiva das Comemorações do V Centenário da Morte do Infante D. Henrique, 1962, pp. 287-289. Citada en SANTAREM, Visconde de - Quadro elementar ... Vol. 8, pp. 404-405.

163. Así lo atestiguan las numerosas súplicas y bulas publicadas en Monumenta Henricina. Vols. 2-3. Coimbra: Comissão Executiva das Comemorações do V Centenário da Morte do Infante D. Henrique, 1962-1964. Siendo la base material de la expasión portuguesa según WITTE, CharlesMartial de - Les bulles pontificales et l'expansion portugaise au XVe siècle. Lovaina la Nueva: Université catholique de Louvain, 1958.

164. EUBEL, Konrad - Hierarchia Catholica Medii Aevi ..., p. 407.

165. ASV, Registra Lateraniense, registro 32, 131r. Citado en EUBEL, Konrad - Hierarchia Catholica Medii Aevi ..., p. 236.

166. ASV, Registra Lateraniense, registro 233, 301r. Citado en EUBEL, Konrad - Hierarchia Catholica Medii Aevi ..., p. 507.

167. DÍAZ MARTÍN, Luis Vicente - "Los inicios en política internacional de Castilla (1360-1410)". in RUCQUOI, Adeline (coord.) - Realidad e imágenes de poder. España a fines de la Edad Media. Valladolid: Ámbito Ediciones, 1988, pp. 57-83.

\section{RESÚMENES}

La llegada al trono de la dinastía portuguesa Avis encarnada en la persona de Juan I de Portugal supuso la necesidad de llevar a cabo iniciativas diplomáticas destinadas a garantizar la supervivencia de la dinastía, la cual entrañaba alcanzar la legitimación de la nueva situación política. Eclesiásticos ligados a la administración del reino, entre los que destacan figuras como João Afonso Esteves de Azambuja o Rui Lorenço, pusieron sus conocimientos, su experiencia y su prestigio al servicio de las exigencias del programa diplomático de la nueva dinastía. Unos recursos humanos escasos y apreciados que no pudieron abarcar todos los campos de actuación de la política exterior joanina, y se especializaron en tres cuestiones: las negociaciones con el pontificado, la construcción de la paz con los castellanos y la participación en la solución del Gran Cisma de Occidente mediante los concilios ecuménicos. Negociadores duros y persistentes que aprovecharon estos encargos para progresar en su carrera eclesiástica mediante la consecución de beneficios, unas veces ofrecidos por el pontífice para ganarse su favor, y otras veces por su monarca como reconocimiento tras alcanzar exitosamente los objetivos marcados.

The accesion to the throne of the Portuguese Avis dynasty embodied in the person of John I of Portugal implied the need to carry out diplomatic initiatives aimed at guaranteeing the survival, which involved achieving the legitimation of the new political situation. Distinguised ecclesiastics linked to the administration of the kingdom, among which was João Afonso Esteves de Azambuja or Rui Lorenço, put their knowledge, experience and prestige at the service of the 
demands of the diplomatic program of the new dynasty. Scarce and appreciated human resources that they could not cover all the fields of action of the John I of Portugal's foreign policy, reason why they specialized in three questions: the negotiations with the pontificate to legitimize John I of Portugal, the construction of peace with the Kingdom of Castile, and the participacion in the ecumenical councils that led to a solution for the Great Occidental Schism. Hard and persistent negotiators who took advantage of these diplomatic assignments to advance in their ecclesiastical career by achieving ecclesiastical benefits, sometimes offered by a Pope, which tried to win their favor, and other times offered by their monarch as recognition after successfully achieving the diplomatic objectives.

\section{ÍNDICE}

Keywords: Diplomacy, Ambassadors, Ecclesiastics, Legitimation, Avis dynasty

Palabras claves: Diplomacia, Embajadores, Eclesiásticos, Legitimación, Dinastia Avis

\section{AUTOR}

\section{NÉSTOR VIGIL MONTES}

Universidade de Évora, CIDEHUS - Centro Interdisciplinar de História, Culturas e Sociedades 7000

Évora, Portugal. Vigilnestor@gmail.com. https://orcid.org/0000-0002-1163-2228 